\title{
Leptospiral Infection, Pathogenesis and Its Diagnosis-A Review
}

\author{
Antony V. Samrot ${ }^{1, *(D)}$, Tan Chuan Sean ${ }^{1} \mathbb{D}$, Karanam Sai Bhavya ${ }^{2}$, Chamarthy Sai Sahithya ${ }^{2}$, \\ SaiPriya Chandrasekaran ${ }^{2}$, Raji Palanisamy ${ }^{2}$, Emilin Renitta Robinson ${ }^{3}$ (D), Suresh Kumar Subbiah ${ }^{4,5,6}$ (D) \\ and Pooi Ling Mok $5,6,7,8, *$ (D)
}

1 School of Bioscience, Faculty of Medicine, Bioscience and Nursing, MAHSA University, Jenjarom, Selangor 42610, Malaysia; tanchuansean@gmail.com

2 Department of Biotechnology, School of Bio and Chemical Engineering, Sathyabama Institute of Science and Technology, Jeppiaar Nagar, Chennai, Tamil Nadu 627 011, India; saibhavyakaranam@gmail.com (K.S.B.); saisahithya1998@gmail.com (C.S.S.); saipriya24c@gmail.com (S.C.); raji.naomi10@gmail.com (R.P.)

3 Department of Food Processing Technology, Karunya Institute of Technology and Science, Coimbatore, Tamil Nadu 641 114, India; emilinrenitta@gmail.com

4 Department of Medical Microbiology and Parasitology, Faculty of Medicine and Health Sciences, Universiti Putra Malaysia, UPM Serdang, Selangor 43400, Malaysia; sureshkudsc@gmail.com

5 Department of Biotechnology, Bharath Institute of Higher Education and Research (BIHER), Selaiyur, Tamil Nadu 600 073, India

6 Genetics and Regenerative Medicine Research Centre, Faculty of Medicine and Health Sciences, Universiti Putra Malaysia, UPM Serdang, Selangor 43400, Malaysia

7 Department of Biomedical Science, Faculty of Medicine and Health Sciences, Universiti Putra Malaysia, UPM Serdang, Selangor 43400, Malaysia

8 Department of Clinical Laboratory Sciences, College of Applied Medical Sciences, Jouf University, Sakaka P.O. Box 2014, Aljouf Province, Saudi Arabia check for
updates

Citation: Samrot, A.V.; Sean, T.C.; Bhavya, K.S.; Sahithya, C.S.; Chan-drasekaran, S.; Palanisamy, R.; Robinson, E.R.; Subbiah, S.K.; Mok, P.L. Leptospiral Infection, Pathogenesis and Its Diagnosis-A Review. Pathogens 2021, 10, 145. https://doi.org/10.3390/ pathogens 10020145

Received: 4 November 2020 Accepted: 9 December 2020 Published: 1 February 2021

Publisher's Note: MDPI stays neutral with regard to jurisdictional claims in published maps and institutional affiliations.

Copyright: (c) 2021 by the authors. Licensee MDPI, Basel, Switzerland. This article is an open access article distributed under the terms and conditions of the Creative Commons Attribution (CC BY) license (https:/ / creativecommons.org/licenses/by/ $4.0 /)$.
* Correspondence: antony.s@mahsa.edu.my (A.V.S.); rachelmok2005@gmail.com (P.L.M.)

\begin{abstract}
Leptospirosis is a perplexing conundrum for many. In the existing literature, the pathophysiological mechanisms pertaining to leptospirosis is still not understood in full. Considered as a neglected tropical zoonotic disease, leptospirosis is culminating as a serious problem worldwide, seemingly existing as co-infections with various other unrelated diseases, including dengue and malaria. Misdiagnosis is also common as non-specific symptoms are documented extensively in the literature. This can easily lead to death, as the severe form of leptospirosis (Weil's disease) manifests as a complex of systemic complications, especially renal failure. The virulence of Leptospira sp. is usually attributed to the outer membrane proteins, including LipL32. With an armament of virulence factors at their disposal, their ability to easily adhere, invade and replicate within cells calls for a swift refinement in research progress to establish their exact pathophysiological framework. As an effort to reconstitute the current knowledge on leptospirosis, the basis of leptospiral infection, including its risk factors, classification, morphology, transmission, pathogenesis, co-infections and clinical manifestations are highlighted in this review. The various diagnostic techniques are also outlined with emphasis on their respective pros and cons.
\end{abstract}

Keywords: leptospirosis; leptospiral proteins; pathogenesis; diagnosis

\section{Introduction}

Infectious diseases are caused by a wide variety of pathogens, including bacteria, fungi, parasites and viruses. These microorganisms have the ability to transfer from one host to another, potentially culminating into worldwide pandemics. The infective capability of such microorganisms is augmented by a multitude of factors, especially the migratory behaviour of populations across various countries [1]. Recent improvements in preventive and therapeutic regimens have inadvertently established the false notion that infectious diseases are not significant threats to public health, but in reality, they still persist as one of 
the major causes of high morbidity and mortality rates every year [2]. Infectious diseases by means of animal or vector transmission are known as zoonoses. Strictly speaking, zoonoses involves a particular pathogen that transmits from an animal (non-human) to a human host [3]. A global-wide analysis from 1940 to the early 20th century found that $60.3 \%$ of emerging infectious diseases (EIDs) were caused by fast-growing zoonotic pathogens [4,5]. One of the most notable zoonotic infections is leptospirosis, which is caused by Leptospira sp. [6]. Based on its thin structure and spiral shape, the term "Leptospira" was first coined by Noguchi [6] who suggested the term to be put forward as a new genus. In Brazil, a study by Mayer et al. [7] evidently demonstrated the presence of Leptospira sp. in bats (one of the many vectors of leptospirosis), further reinforcing the association of Leptospira to its epidemiological data in the existing literature.

According to the Leptospirosis Burden Epidemiology Reference Group (LERG), the risk factors for leptospirosis increases due to rainfall, flooding, open sewers, crowding, populace, animal contacts and poor sanitation [8]. Recent studies have demonstrated that the outbreak of leptospirosis in Malaysia and Brazil occurred after major floods $[9,10]$. This reinforces the tendency for leptospirosis to culminate into a worldwide outbreak as several countries (in addition to Malaysia and Brazil) are prone to the after effects of global warming and severe floods. Besides that, the prevalence of outbreaks is highly associated with various outdoor activities, such as wildlife recreational programs, adventure travels and army expeditions [11]. To reinforce, a study by Dierks et al. [12] reported that US marine trainees situated in Japan were found to be inflicted with leptospirosis, as they were constantly exposed to stagnant waters in a simulated jungle warfare environment. Since warm and humid condition incites the transmission of leptospirosis [13], outbreaks typically occur in tropical areas [14] and sometimes during summer or fall in temperate regions. It is also estimated that approximately 500,000 high-risk cases occur globally with a $30 \%$ fatality rate per annum [15]. Recent studies have demonstrated the global incidence of leptospirosis, as evidently demonstrated in Italy [16], Pakistan [17], Japan [18], Brazil [19], India [20] and Sri Lanka [21]. Records of epidemics were found widely spread between 2000 to 2010 in Nicaragua, Sri Lanka and Philippines [14].

With a case fatality ratio of 26.89 out of 7587 cases in 10 years [2], leptospirosis still remains as one of the major health concerns worldwide. However, the false notion regarding the severity and global impact of leptospirosis hinders the worldwide surveillance, control and detection of the disease. Hartskeerl et al. [22] emphasized that the mortality and morbidity rates of leptospirosis are significantly underestimated due to the lack of notification and epidemiological effort in various countries. Moreover, only those with severe leptospirosis are taken into account for the estimation of the disease's incidence rate. The lack of knowledge on leptospirosis worldwide worsens the aforementioned problem. As an effort to reconstitute the current knowledge on leptospirosis, the present review discusses the disease from all angles pertaining to its risk factors, causative agent, pathogenesis, clinical manifestations and diagnostic techniques.

\section{Risk Factors}

Occupation, migratory behaviour, gender and age are all significant risk factors of leptospirosis. In the past, leptospirosis was first considered as an occupational disease, whereby coal miners were the first occupational risk groups to be documented in the literature [23]. In all actuality, various mammals including feral, farm and pet animals harbours the disease-causing agent. This extends the occupational risk to wider lengths as it is capable of infecting farmers, miners, slaughterhouse laborers, pet traders, veterinarians, rodent catchers, sewer workers, garbage collectors and livestock ranchers, as these job scopes have continuous and constant contact with various animals throughout their duty $[14,22]$. Although they are not considered as occupational risk factors, water-based sports [24] and international travels [22] are known to contribute significantly to the rapid transmission of leptospirosis. 
Due to the rising risk of leptospirosis in various parts of the world, the World Health Organization (WHO) initiated the Leptospirosis Burden Epidemiology Reference Group (LERG) which aims to assess the overall population health by quantifying the morbidity and mortality rates due to leptospirosis [25]. A report submitted from the second LERG meeting stated that the median case-fatality percentage was significantly higher in women as compared to men [26]. However, that does not mean that women are more likely to be infected with the disease. From the same report, men are actually more likely to be infected with leptospirosis as they are more prone to occupational exposure in outdoor settings. For men, the median incidence of the disease was the highest for those older than the age of 59 , followed by those between the ages of 20 to 29 . For women, approximately $37 \%$ of leptospirosis cases were reported for those aged between 40 and 49 [26]. As evident from the aforementioned data, it can be inferred that both gender and age play a significant role in the occurrence and fatality of leptospirosis.

\section{Classification of Leptospira}

Leptospires are classified into various serovars based on the distinct expression of surface-exposed epitopes in a mosaic of their lipopolysaccharide (LPS) antigens [27]. Initially, Leptospira was only classified into L. interrogans and L. biflexa, which clearly divides the pathogenic and non-pathogenic species. Later on, these two classifications were further divided into specific serovars based on the presence of homologous antigens (nearly 60 serovars under L. biflexa and at least 225 serovars under L. interrogans). As the years go by, at least 21 more species have been identified under Leptospira with more than 200 specific serovars $[27,28]$. In all actuality, the classification of Leptospira is vast and more sophisticated than it seems. The present review concentrates on the three basic classifications of Leptospira (Figure 1) according to their capability to cause disease.

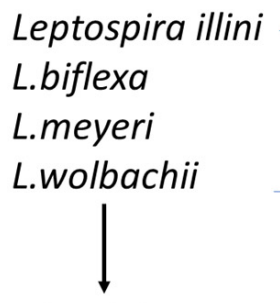

L.inadai

L.parva<smiles>CCCCCC</smiles>

L. kirschnerii L.interrogans
Saprophytic (prefers to live between $1{ }^{\circ} \mathrm{C}$ and $35{ }^{\circ} \mathrm{C}$ and do not cause disease)

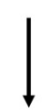

Biochemical intermediate (lives between $1{ }^{\circ} \mathrm{C}$ and $37^{\circ} \mathrm{C}$ and do live as saprophytes as well as pathogens)<smiles>CCCC</smiles>

\section{Pathogenic (lives between $20^{\circ} \mathrm{C}$ and $37^{\circ} \mathrm{C}$ and cause diseases in rodents and humans)}

Figure 1. Illustration depicting the relationship between pathogenic, intermediate and saprophytic Leptospira and the distinct differences between them.

Even though the saprophytic and pathogenic types of Leptospira have some similarities in their structure and genetic makeup, they vary by other factors such as the ability to cause disease and temperature withstanding capacity. Saprophytic leptospires are capable of growing at low temperatures $\left(5-35^{\circ} \mathrm{C}\right)$, found naturally in soil and water but they do not have the capability to cause any infections. The first saprophytic leptospire to be sequenced (also the major saprophytic species) is Leptospira biflexa. It consists of a large number of serovars and they are usually found on moist soils and on water surfaces (rarely found in humans and other animals) [28,29]. Other saprophytic leptospires include L. meyeri, L. wolbachii, L. yanagawae, L. vanthielii and L. terpstrae [28]. Similarly like L.biflexa, the aforementioned organisms are not capable of inflicting diseases. Although it is rare, 
saprophytic leptospires were documented to be found in the urine of various mammals. These organisms are distinctively identified by the presence of two bundles of cytoplasmic tubules as well as flagella, with their basal structures resembling that of Gram-positive bacteria [30]. As these organisms have somewhat similar structures with other species under the same genus, the ability to easily manipulate and control saprophytic leptospires makes them excellent and safer alternatives (as compared to pathogenic leptospires) for structural studies [31].

Intermediate leptospires exist as the biochemical intermediate of saprophytic and pathogenic leptospires One major leptospire from this group is Leptospira parva, which is considered as the biochemical intermediate of L. interrogans and L. biflexa [29]. L. parvais capable of co-existing with various saprophytic and pathogenic leptospires [32]. With more than 5 identified species from this group [28], other notable intermediate leptospires include L. broomi, L. inadai, L. licerasiae, L. wolffii and L. fainei [33]. Pathogenic leptospires require temperatures ranging from $20-35^{\circ} \mathrm{C}$, are usually found in rodents and have flagella with basal structures resembling that of Gram-negative bacteria [29]. Compared to saprophytic leptospires, the leptospires from this group are more significant to healthcare. This is because the various members of this group, including L. interrogans, L. weilii, L. noguchii, L. borgpetersenii [34], L. kirschneri and L. santarosai [19] are capable of inflicting leptospirosis, subsequently influencing morbidity and mortality rates.

\section{Morphology}

Leptospires are aerobic and slow-growing organisms that are highly susceptible towards drought and hypertonic conditions [35]. Attributed to various ocular manifestations [36,37], these organisms are helical-shaped with distinct hook-ends that allows them to be clearly differentiated from other spirochaetes. In terms of their size, they are thin and long with a thickness of about 0.1 to $0.15 \mu \mathrm{m}$ and 6 to $20 \mu \mathrm{m}$ in length [24]. Jutras et al. [38] documented the ability of leptospires to elongate in a lateral fashion by synthesizing peptidoglycan for growth. Collectively, the aforementioned morphological features enable leptospires to easily burrow into tissues of their victims. Jackson et al. [31] demonstrated that the presence of bactofilins in L. biflexa are responsible for the retainment of the organism's helical shape. Bactofilins were also hypothesized to have played a role in the rapid movement of the organism, but as of date their exact functions are yet to be determined. The chromosomal DNA of leptospires is distributed along the length of the cell, rather than the center [39]. Like most Gram-negative bacteria, Leptospira spp. consists of an outer membrane with various functional proteins. Uniquely, they also consist of periplasmic flagella that allows the bacteria to be motile. As these morphological features contribute significantly to the clinical importance of Leptospira, they are selectively discussed in further in detail as following.

\subsection{Cell Outer Membrane Structure and Its Proteins}

Leptospira consists of an outer membrane (majorly composed of LPS) that is quite similar to that of Brachyspira, allowing them to stand out from other spirochaetes such as Treponema and Borrelia [28,40]. Although the outer membranal structure of leptospires adopts similar characteristics from both Gram-negative and Gram-positive bacteria, the endotoxic potential of Leptospiral LPS is significantly lower as compared to the average Gram-negative LPS [41]. This allows us to infer that other proteinaceous structures found on the outer membrane of leptospires contributes more to their virulence and pathogenicity. When leptospires are suspended in distilled water and subsequently dried, they are capable of forming a sheath-like structure around their periphery [42]. This was earlier considered to be the after effects of bacterial washing and the mere observation of cell wall-like structures of Leptospira. This hypothesis was later reinforced by Anderson et al. [43], as they found the outer sheath and the wall membrane are important control mechanisms for the viability and permeability of leptospires. From the aforementioned findings, it is evident that the outer membrane of leptospires is functionally versatile due to the complex com- 
position of the proteinaceous components found there. As an effort to better understand the multifold functions of Leptospira's outer membrane, the following subsections review and distinguish the roles of various leptospiral outer membrane proteins described in the existing literature.

\subsubsection{Outer Membrane Proteins}

Unlike other spirochaetes, leptospires have a distinct outer membrane that consists of LPS with various beta barrel transmembrane proteins [44] (Figure 2). Typically, the outer membrane proteins functionally act as diffusion barriers, as well as being involved in the process of septum formation and nutrient uptake for growth [45]. Despite these classical life-sustaining functions, these proteins were also shown to demonstrate some level of virulence against various host mechanisms as they are usually engaged in scuffles with host defence units (since they are directly exposed to host environment in the exterior) [46]. Lipoprotein L32 (LipL32) [47], lipopolysaccharides (LPS) [48], Leptospira immunoglobulinlike proteins (Lig) [49], Leptospira endostatin-like proteins (Len) [50,51] and Leptospira OmpA-like lipoprotein (Loa22) [52] are well-established in the existing literature due to their highly virulent nature. With the help of various surfactants, a multitude of approaches were successfully carried out to singly isolate the aforementioned proteins, allowing them to be successfully classified into five major protein classes (Figure 3) [53-78].

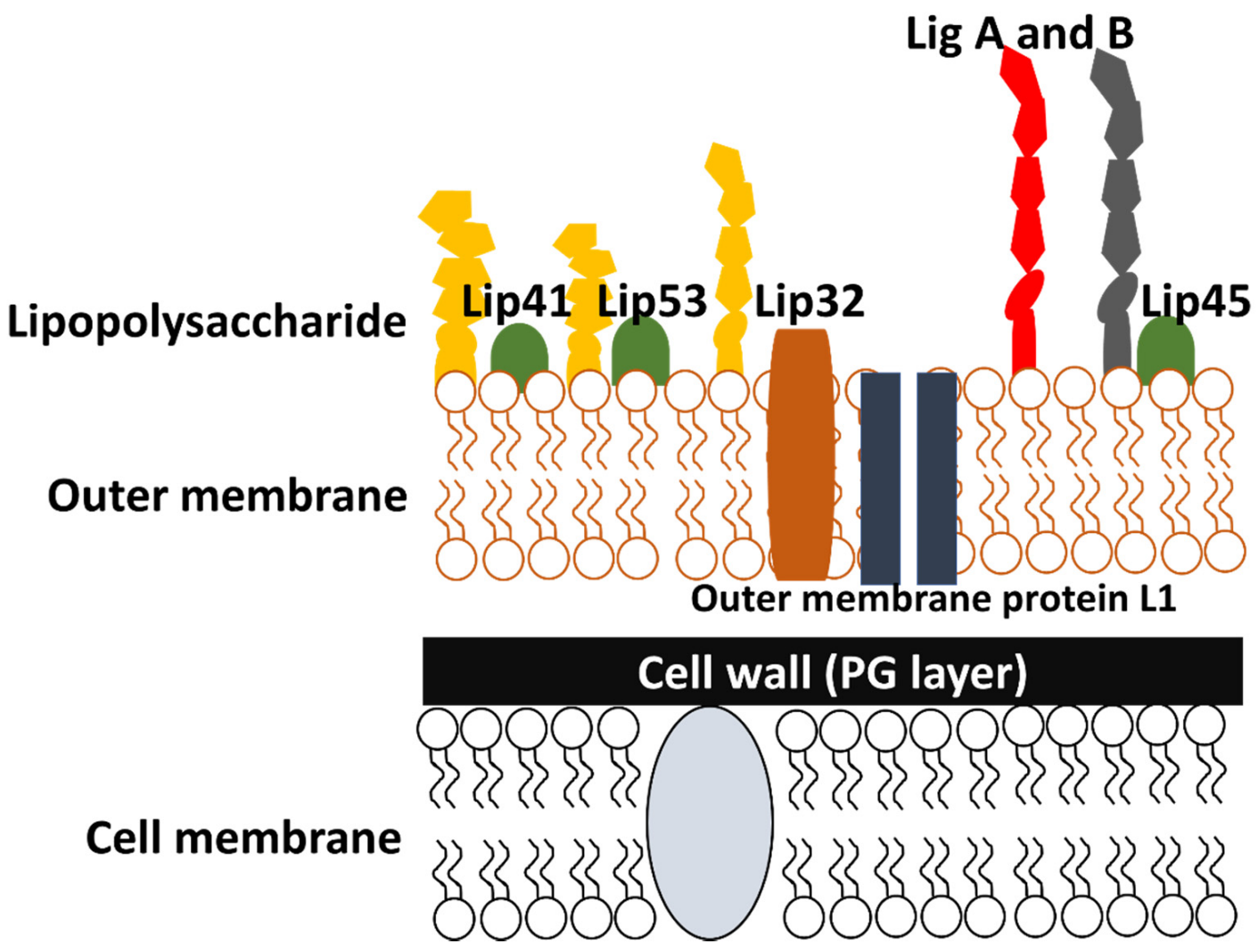

Figure 2. Illustration depicting the outer layers of Leptospira species, highlighting the various proteins found on the outer membrane. 


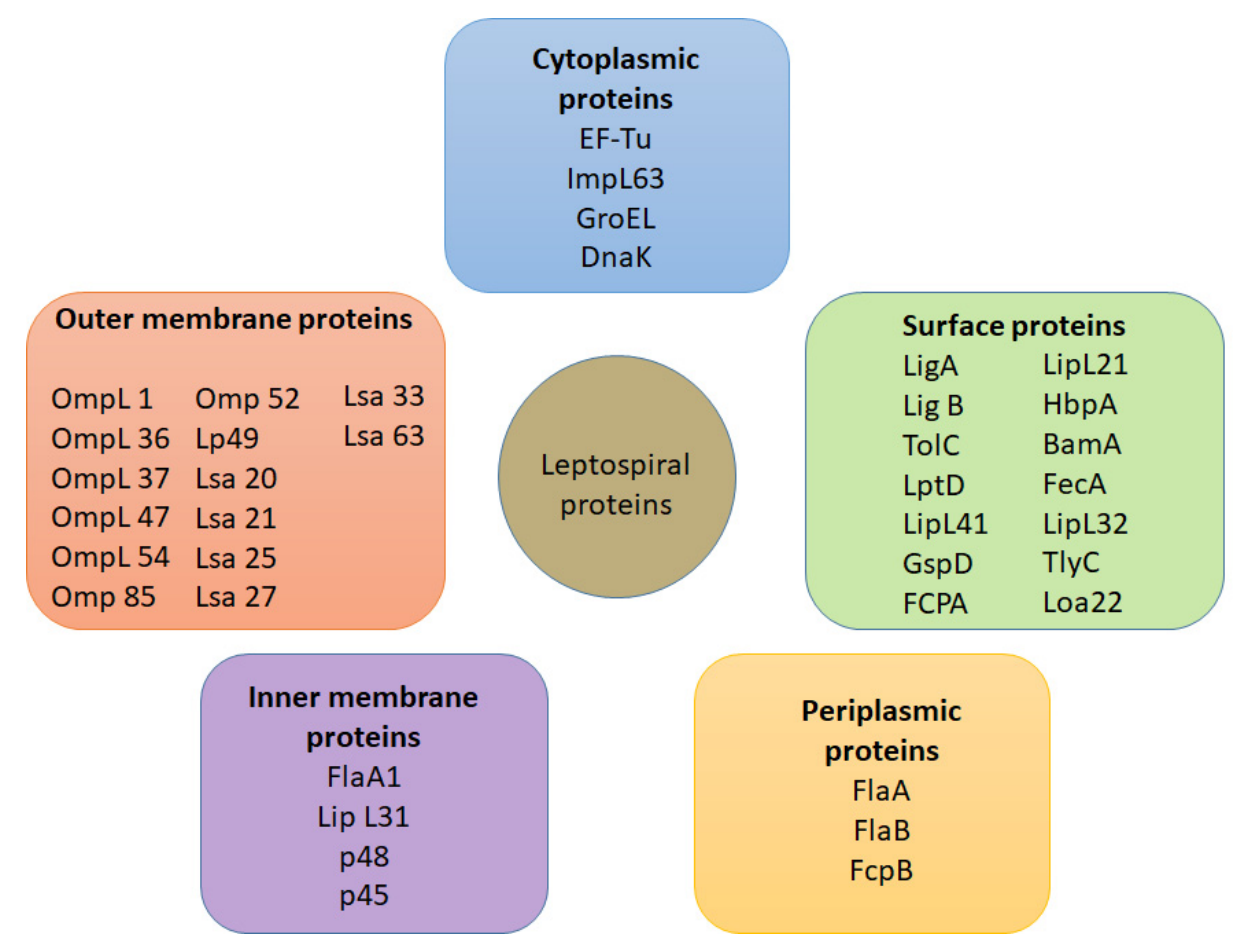

Figure 3. Pictorial representation of notable leptospiral proteins [44,51,52,57-78].

\subsubsection{LipL32}

Lipoprotein L32 (LipL32) is the most abundant outer membrane protein found in Leptospira species. It is a lipoprotein with a single tag at its $\mathrm{N}$-terminal $[57,79,80]$ and specific lipid-based modification at its Cys residue [81]. Various affinity-based studies have found that the intermediate domain and C-terminal of LipL32 are vital for its interaction with a multitude of components in the extracellular matrix (ECM), including laminin, collagen and fibronectin [82,83]. In terms of its virulence, Witchell et al. [84] confirmed that post translational modification of LipL32 is related to host innate immunity as it directly induces host inflammatory response. This most often leads to tubulointerstitial nephritis as large amounts of inflammatory mediators, including monocyte chemoattractant protein-1 (MCP-1), RANTES, inducible nitric oxide synthase (iNOS) and tumour necrosis factor- $\alpha$ (TNF- $\alpha)$ are produced in the vicinity of renal cells [47]. In addition, LipL32 also acts as a haemolysin, which in turn induces proinflammatory cytokines through the various toll-like receptor (TLR) signalling pathways [85]. As established in the existing literature, there are generally two types of TLRs (TLR2 and TLR4) involved in leptospirosis, but Yang et al. [86] accentuated the pathogenic significance of TLR2 as it directly interacts with LipL32. Lo et al. [87] also found that the calcium-binding cluster (consisting of several essential residues such as Asp, Thr and Tyr) present on LipL32 is responsible for sustaining LipL32 conformation for proper TLR2-mediated inflammatory responses in host renal cells. In terms of their diagnostic applications, LipL32 is used as a target gene in multiplex polymerase chain reaction (PCR) which significantly improves the diagnostic sensitivity and specificity of leptospiral infections [88]. Sumarningsih et al. [89] reported the use of recombinant LipL32 as an antigen in enzyme-linked immunosorbent assay (ELISA), allowing for a safer and easier approach in leptospiral diagnosis.

\subsubsection{OmpL1}

Outer membrane protein L1 (OmpL1) is a transmembrane protein with 320 amino acids that functionally acts as a porin (diffusion channels) in all pathogenic species of Leptospira [90,91]. The ompL1 gene, which encodes for the OmpL1 protein, is divided into three groups (ompL1/1, ompL1/2 and ompL1/3) based on the molecular phylogenetic rela- 
tionship of their amino acid and nucleotide sequences [91]. As reported by Dong et al. [91], all three of these genes were found in pathogenic leptospires in China, whereby the distinct protein products are naturally expressed on the surface of the leptospires. OmpL1 acts as an ECM-binding protein that commonly binds to fibronectin and laminin, and is also capable of interacting with plasminogen (PLG) as its receptor $[60,92]$. Through in vivo studies, Fernandes et al. [60] described the capability of OmpL1 in promoting the proliferation of lymphocytes and stimulating the release of cytokines [93] from T-helper 1 and T-helper 2 cells. These findings were reinforced by a study done by Haake et al. [94], in which they found that OmpL1 provided a significant level of immune protection effect, paving the way for vaccine production against Leptospira. In diagnosis, the high percentage of true-positive leptospirosis cases (microscopic agglutination test-positive) is largely due to the high specificity of the IgG antibody-response towards OmpL1, enabling the clear differentiation from other diseases [60].

\subsubsection{Loa22}

Loa22 is a $22 \mathrm{kDa}$ bipartite leptospiral lipoprotein with a C-terminal OmpA domain (consisting of approximately 195 amino acids) and an N-terminal domain [52,95]. This lipoprotein has an atypical Leu residue prior to Cys with a single cleavage site between the 20th and 21st residues. By studying the amino acid sequence of the C-terminal OmpA domain, it is well-established that other leptospiral outer membrane proteins demonstrated sequence homology with OmpA. In addition, Koizumi et al. [95] found that Loa22 is a surface-exposed protein, corroborating with the more recent immunofluorescent-based findings by Ristow et al. [52].

\subsubsection{LigB}

Leptospira immunoglobulin-like protein B (LigB) is capable of binding to several ECM components such as fibronectin, collagen, laminin fibrinogen and elastin. There are mainly three classes of leptospiral immunoglobin proteins-namely, LigA, LigB and LigC which possesses 13, 12 and 13 immunoglobulin-like domains, respectively [51,96,97]. The genes coding for the respective $\operatorname{Lig}$ proteins, $\operatorname{lig} A, \operatorname{lig} B$ and $\operatorname{lig} C$ encodes the virulence determinants in pathogenic leptospires. As the most clinically significant of the three, lig $B$ is present in almost all Leptospira species, including L. weilii, L. interrogans, L. kirschneri, L. borgpetersenii and L. noguchii, while ligA is present in only some species of Leptospira, such as L. interrogans and L. kirschneri. ligC is a pseudogene found in certain Leptospiral species, including L. weilii, L. interrogans and L. kirschneri [98]. In terms of their sequence homology, the amino acid sequences found on the $\mathrm{N}$-terminals of LigA and LigB are exactly identical whereas the amino acid sequences found on their C-terminals are only $34 \%$ similar. Overall, LigC only shows $38 \%$ sequence homology with LigA and LigB, highlighting it as a fairly distant counterpart of the two Lig immunoglobulins $[99,100]$. The expression of these proteins is controlled by physiological osmolarity, which is well-acknowledged as a key environmental signal for leptospires to enhance their binding to host cells [101,102]. A study by Lin et al. [103] found that LigB consists of two variable regions (LigBCen and LigBCtv) that enables leptospires to bind effectively to host cells. In terms of their diagnostic value, various studies have documented the possibility of utilizing the Lig proteins as diagnostic markers for early diagnosis of leptospirosis [104] and also as a potential candidate for vaccine development [105].

\subsubsection{LenA}

Leptospiral endostatin-like protein A (LenA) is also known as leptospiral surface adhesin protein (Lsa24) [106] and leptospiral factor H binding protein (LfhA) [107]. Lsa24 and LfhA are found to be the same protein and thus they are collectively renamed as a single entity: LenA. Verma et al. [107] reported that LenA is capable of interacting with human factor H-related protein 1 (FHR-1), which has a high degree of similarity with factor $\mathrm{H}$ [108]. Factor $\mathrm{H}$ is a fluid-phase regulator that plays a vital role during activation of 
the alternative complement pathway in host immune systems. As their outer membrane consists of LenA, pathogenic leptospires are capable of binding to factor $\mathrm{H}$, consequently becoming resistant to complement mediated-killing via the alternative pathway. The gene sequence of LenA is highly conserved and are thought to encode for membrane associated lipoproteins in Leptospira [46]. Vieira et al. [109] reported that the lysine residues found on LenA has the ability to bind with plasminogen in a dose dependent manner. This in turn generates the enzymatically active plasmin on the leptospires' surface, which can be detrimental to host tissues as plasmin can easily degrade ECM components (aligning with leptospiral host tissue penetration) [110].

\subsection{Periplasmic Flagella}

Contrary to most bacteria, Leptospira consists of two periplasmic flagellum (also known as axial filament and endoflagella) that are anchored to opposite ends of the organism and extends horizontally in the periplasmic space. Although periplasmic flagella primarily provide leptospires with the ability to move about via translational and non-translational movements [41], they also serve as cytoskeleton and maintains the flat-wavy shape of the organism [111]. Each of the periplasmic flagellum extends to a very short distance from their respective poles, visualized as distinct hook-like end [112]. Both extensions from opposite ends terminate at the central region of leptospires without touching each other [111]. Takabe et al. [111] found that the swimming manner of leptospires differ according to the viscosity of the media they are suspended in. In non-viscous media, the organism mainly utilizes their hook-like ends for motility support, while a screw-like motion is utilized in the case of viscous media. In terms of their morphological framework, leptospiral flagellum consists of three major parts: the filament, flexible hook and the basal complex [39].

In L. pomona, a typical filament is about 100-120 A in diameter [113]. In leptospires, this structure is connected to the basal complex with the help of a flexible hook. The hookfilament junction is composed of FlgK and FlgL proteins, which keeps the filaments affixed to their respective poles [39]. Both of the filaments extend from opposite ends of the organism and extend along the protoplasmic cylinder until it reaches the central region. Leptospires are thus capable of achieving motility via rotational movement of these filaments [24]. Each flagellar filament consists of a cylindrical core that is made up of four major subunits (FlaB1, FlaB2, FlaB3 and FlaB4) and are enclosed by an outer sheath made up of FcpA, FlaA1 and FlaA2 subunits [32,114]. The FlaB1 and FcpA subunits interact with one another to ensure that the cylindrical core and the outer sheath carry out their contractional actions in a concerted fashion. Various literatures have found that the thickness of the outer sheath largely depends upon the identity of the leptospires (Table 1).

Table 1. Number of cell layers based on the leptospiral strains.

\begin{tabular}{ccc}
\hline Strain & No. of Layers & Reference \\
\hline L. pomona & $\begin{array}{c}3 \text { layers } \\
\text { (dense-light-dense) }\end{array}$ & {$[113]$} \\
\hline L. icterohaemorrhagiae & $\begin{array}{c}5 \text { layers } \\
\text { (dense-light-dense-light-dense) }\end{array}$ & {$[115]$} \\
\hline A large spirochaete found in ANU-G lesions & $\begin{array}{c}5 \text { layers } \\
\text { (dense-light-dense-light-dense) }\end{array}$ & {$[116]$} \\
\hline
\end{tabular}

Raddi et al. [117] discovered that there are novel periplasmic filaments (PFils) existing in the periplasmic space. With the help of cryo-electron tomography (cryo-ET), PFils were found to be smaller than flagellar filaments (approximately 8 vs. $22 \mathrm{~nm}$ ). Evidently, the PFils were found to be wrapping around the organism's cell body, especially in the central region that is devoid of periplasmic flagella. Additionally, Sasaki et al. [72] discovered that 
FcpA interacts with FlaA2 to produce the coiling force of PFils, further potentiating the organism's movement capabilities.

The basal complex acts as a transmembrane rotary motor, contributing significantly to the motility of Leptospira as it allows the flagellar filaments (bridged by the hook) to rotate while remaining affixed to the same axis [39]. In terms of their morphological framework, it is well-established that the basal complex of leptospiral flagella is fairly similar to that of Gram-negative bacteria [32]. It is made up of various subunits, including the rod (directly attached to the hook), L ring, P ring and MS (membrane/supramembrane) ring. In actuality, the basal complex in leptospires is much larger and sophisticated compared to other common bacterial models (such as Escherichia coli). Raddi et al. [117] documented that leptospiral basal complex consists of additional subunits, including a flagellar $\mathrm{C}$ ring, an export apparatus as well as a stator. The basal complex of leptospires also consists of a collar, briefly described as a large and complex structure that is anchored to the MS ring and the inner membrane [118]. Moon et al. [119] suggested that the collar (specifically collar protein $\mathrm{FlbB}$ ) may be vital for leptospires to adjust the orientation of their periplasmic flagella. From these findings, it is evident that the structure of leptospiral flagella is more sophisticated than previously thought, reinforcing the fact that other new proteins contributing to the motility of leptospires could be discovered in the near future.

\section{Antigens Involved in Leptospiral Infection}

A multitude of leptospiral antigens were successfully isolated and characterized for diagnostic and research purposes in the existing literature [120]. The classification of Leptospira largely depends upon the type of antigens expressed on their surface. In host systems, leptospiral antigens are primarily recognized by two receptors: toll-like receptors and NOD-like receptors [121]. Most of the anti-Leptospira antibodies are produced against the organism's LPS, which are composed of polysaccharides, proteins and lipids [41]. Isogai et al. [122] documented that LPS in leptospires are antigenically active and are found to be unique amongst leptospiral serogroups. To reinforce, the O-antigen present in leptospiral LPS differs from one strain to another [123]. Therefore, isolating this particular antigen would greatly assist in the detection of specific leptospiral strains. In addition, Nally et al. [124] inferred that the synthesis of O-antigen may be specifically regulated by leptospires depending upon the animal host infected, further reinforcing their specificity.

Type-specific main (TM) antigen is another surface antigen found in leptospires. As its name implies, TM antigen is highly serovar-specific. A study by Adachi and Yanagawa [125] found that the presence of homologous TM antigen inhibits the microscopic agglutination of leptospires. In contrast, no inhibition was evident when heterologous TM antigens were utilized. From these findings, the authors inferred that TM antigen is present at the surface of Leptospira as it evidently participates in the microscopic agglutination of leptospires with antisera. Besides that, F4 is also another surface-specific fimbrial antigen that is involved in the process of haemagglutination [126]. This antigen was once assumed to be similar as TM antigen, but Adler et al. [127] found that both of these antigens produced unique results during immunodiffusion and haemagglutination tests. Moreover, F4 was found to cross-react widely amongst different serovar groups, whilst TM is strictly serovar-specific. The aforementioned findings further reinforced the contention that these two antigens are separate entities (with different antigenic identities) located at the surface of leptospires.

As documented by Guerreiro et al. [59], various leptospiral antigens are involved in the humoral immune response towards leptospirosis-namely, LipL32 and LipL4 in the outer membrane portion, heat shock proteins (GroEL and DnaK) in the cytoplasmic fraction and P37 in the periplasmic portion. GroEL and DnaK are heat shock proteins that are highly conserved in leptospiral species. These proteins provide unique responses in different strains and their high adaptability towards temperature shifts play a pivotal role in the virulence and infective potential of leptospires [128]. Natarajaseenivasan et al. [129] found that acute phase sera detect GroEL more frequently than other proteins, signifying 
its role during the acute phase of leptospirosis. As evident from increased levels of total IgG, IL-10 and lymphocytic proliferation, Atzingen et al. [130] demonstrated that the deliberate fusion of DnaK proteins with other leptospiral proteins promotes an enhanced immune response, as compared to the singular effects elicited by the individual proteins. Collectively, these findings accentuate the significance of each leptospiral antigen and their distinctive roles during the development of leptospirosis, allowing leptospires to easily infect and inflict harm against host systems.

\section{Transmission and Pathogenesis}

In the existing literature, several antigens have been reported as potential virulence factors of Leptospira, including the various outer membrane proteins, LPS, adhesion molecules and haemolysins. Although leptospires adopt a fairly linear framework of transmission, adhesion and cell entry into host cells, the exact molecular pathophysiology pertaining to leptospirosis is still a perplexing conundrum for many [131]; even so, significant amounts of notable research progress have been made recently. Martins-Pinheiro et al. [132] conducted an in silico search for DNA repair pathways in leptospires, allowing them to identify several important genes required for leptospiral infection. A multitude of key metabolic pathways in Leptospira have also been mapped out or further elucidated, including cobalamin biosynthesis and free radical detoxification [133]. Keeping up with the momentum from the aforementioned contributions, this section reviews the currently established sequential steps in the transmission and pathogenesis of leptospirosis as an attempt to disentangle, unearth and bring clarity to its rather complex mechanisms.

\subsection{Transmission}

Leptospires are primarily transmitted via two exposure routes; either by direct contact with an infected animal, or by indirect contact with environmental media such as soil and water that are contaminated with body fluids (especially urine) of infected animals [134]. Consumption of leptospiral-contaminated water, penetration through open wounds, abrasions and mucous membranes (conjunctival, oral, conjunctival or genital surfaces) are common portals of entry for the bacteria, ultimately bypassing the external host tissue barriers [14,22]. The corkscrew-like motility seen in leptospires allows them to move through more viscous barriers (including host connective tissues) fairly easily, contributing to their highly invasive nature [135]. Stern et al. [136] documented that accidental swallowing while swimming outdoors is a possible risk factor for leptospiral infection, as evident from the 2005 leptospirosis outbreak in Florida amongst adventurer race peers. In the existing literature, rodents [137], pigs [138], horses [139,140], cattle [141], dogs [142,143] and various wild animals such as opossums [19], deer [27] and pinnipeds [134] are some of the established carriers of Leptospira.

According to Levett et al. [144], leptospires have the tendency to inflict chronic renal diseases onto animal carriers; thereby explaining why the urine of Leptospira-infected animals contains large numbers of the organism. These bacteria tend to accumulate at the proximal convoluted tubules of their host, colonizing and multiplying rapidly from the get-go, whilst some others are released into the environment via urination [14]. Although it is well-established that leptospirosis is rarely transmitted from human to human through conventional means (hence the term zoonotic), de Oliveira et al. [145] have shown that it is possible for breast feeding to spread Leptospira from infected mothers to neonates. As reported by Harrison and Fitzgerald [146], sexual intercourse is also a possible transmission route (albeit rare) as there is still a small chance for Leptospiracontaminated urine to be exchanged directly between sexual partners. Infected rodents can also transmit the disease to livestock and pets, further expanding the disease transmission as livestock and pet borne. Overall, the tendency for each transmission route to occur depends upon the demographical, geographical, agricultural and livestock factors of a particular population [137]. 


\subsection{Leptospiraemic Phase}

The early (acute) stage of leptospiral infection is described using various terminologies, such as leptospiraemic [36], anicteric [24] and bacteraemic [147], all of which essentially denotes the same phase of infection. The sudden onset of myalgia, fever and headache are major manifestations of this phase [148]. There are also a few non-specific symptoms such as anorexia, nausea and abdominal pain, which are also seen in other unrelated diseases [147]. According to a study by Banfi et al. [149], leptospires were evidently found in the bloodstream just $10 \mathrm{~min}$ after deliberately infecting test animals via intra-peritoneal, intradermal and intra-ocular administrations. The twisting motion of periplasmic flagella plays a pivotal role in the aforementioned finding, allowing leptospires to enter the host bloodstream in mere minutes [24]. The spontaneous haematogenous dissemination of leptospires is in stark contrast to other spirochete species like Treponema pallidum and Borrelia burgdorferi, which prefers to establish localized infection in the skin and produce obvious lesions. Bacteraemia caused by leptospirosis is well-established to be very different from those caused by typical bacteraemic agents such as Enterobacteriaceae. Werts et al. [48] substantiated the aforesaid statement as they found that human TLR4 can easily recognize very low concentrations of LPS derived from Escherichia coli, but unable to do so in the case of leptospiral LPS. To reinforce, Que-Gewirth et al. [150] documented a very distinctive methylated phosphate residue found on the lipid A of leptospiral LPS, which is not found in other distinct species like E. coli. This allows leptospires to seemingly camouflage themselves from the host innate immune response, essentially providing them enough time to inflict damage before they get detected. Despite all of this, a study by Goris et al. [151] accentuated that the involvement of TLR2, TLR4 and TLR5 are still significant factors in host defense against leptospirosis, and further studies should be carried out to better elucidate the pathophysiological mechanisms of Leptospira.

\subsection{Adhesion and Cell Entry}

Although they are generally considered to be extracellular pathogens (mainly existing in the host bloodstream) [28], leptospires are equipped with an armament of virulence factors, allowing them to easily adhere, enter and replicate within host cells. As such, various studies in the existing literature have suggested that pathogenic leptospires should at least be considered as transiently intracellular, since they were evidently found to replicate and survive within macrophages and other non-phagocytic cells $[28,152,153]$. Spontaneous and recurrent damage in the endothelial lining of small blood vessels is considered to be the major pathological phenomena of leptospirosis, but the exact mechanism as to how leptospires penetrate the endothelium is not fully understood. Barocchi et al. [154] managed to infer that leptospires have the ability to translocate between cells through polarized monolayers, but unable to do so through cell junctions. Through in vitro studies, Banfi et al. [149] found that various proteins are involved in leptospiral adhesion to cells; leptospiral proteins can bind not only to ECM components (fibronectin, elastin, laminin and collagen), but they can also adhere to complement regulators and plasminogen by using LigB and LipL32. As reviewed by Murray [155] and Fernandes et al. [156], a total of 34 and 17 leptospiral proteins were reported to be capable of binding to fibronectin and plasminogen, respectively. The multifunctional aspect of the aforementioned proteins explicitly highlights the sophisticated nature of the mechanistic and pathophysiological framework in leptospires.

According to Liu et al. [157], adhesion-related receptors of leptospires were hypothesized to be localized at their cell terminals (similarly like Treponema denticola). When incubated with J774A.1 cells, leptospires tend to bind to these cells at both ends, forming a dumbbell-like shape. In contrast, incubation with Vero cells did not produce the dumbbell shape as previously described, as the Vero cells only bind to one end of the leptospires. This coincides with their inference that the pattern of attachment seems to be distinctively varied according to the cell lines utilized. This particularly unique fashion of adhesion provides leptospires with a somewhat "customizable" form of cell internalization, ultimately 
becoming an important factor of their virulence. A homologue of mammalian cell entry (Mce) protein, which is normally found in Mycobacterium tuberculosis, are also found in pathogenic leptospires [158]. These proteins are documented to confer leptospires with the ability to adhere to host cells, as inferred from studies done on recombinant Mce-bound integrins [159]. With so many adhesin proteins at their disposal, leptospires are capable of binding to various cells, including endothelial cells, monocytes, kidney epithelial cells and fibroblast cells [41]. As such, these bacteria can colonize, replicate and survive in wide variety of tissues throughout the host system. Liu et al. [157] also inferred that the internalization of leptospires is via receptor-mediated endocytosis. They found that infected cell lines contain numerous leptospiral-laden phagolysosomes, an observation that later contributed to the suggestion that these pathogens could be residing in phagolysosomes for their continual replication and survival. This is reinforced by the fact that leptospires reside temporarily within cells as an effort to avoid complement and antibody-induced killing [41].

\subsection{Weil's Disease}

If leptospirosis is not promptly or adequately treated during the acute phase, leptospires in the bloodstream can sometimes translocate even further to distant host tissues and the disease slowly worsens. This particular phase is commonly known as Weil's disease [24], which is an extremely severe form of leptospirosis. It is also known as the late phase [147], leptospiruria [36] and icteric phase. Essentially, the aforesaid terminologies denote the progression of leptospirosis into a very severe systemic disease, highlighting the tendency for leptospires to inflict system-wide damage that can be detrimental to health Documented to last for up to 30 days, the immune phase typically begins from 7-10 days after the first onset of symptoms [36]. Satiya et al. [160] emphasized that untreated leptospirosis can lead to fatal hepatic manifestations, such as jaundice. Liver failure, kidney failure and respiratory shock are also notable complications of severe leptospirosis. As the disease remains untreated for a long period of time, the organisms become highly invasive as large numbers of cell membrane-degrading enzymes are actively secreted. Other proteins produced during this phase includes orthologs of hemolysin, proteolytic enzymes like collagenase, metalloprotease and thermolysins, which are all necessary for degradation of ECM components and assists their invasion [161]. As such, the host immune system responds by producing large amounts of cytokines and recruiting numerous white blood cells, but these efforts are futile against leptospires, easily leading to multi-organ failure and even death. A summary of the transmission and pathogenesis framework of leptospirosis is illustrated in (Figure 4).

\subsection{Evasion of Host Immune System and Virulence Factors}

Despite ongoing research efforts, the pathophysiological mechanism of leptospirosis remains poorly understood. However, it is theorized that this disease occurs as a result of the host immune response towards the organisms, which by now should be excessively abundant in the blood, liver, lungs, kidneys, cerebrospinal fluid and the aqueous humour among other organs [160]. As leptospires bind to host cells, cytokines (interleukin-6, interleukin-10 and TNF- $\alpha$ ) and antimicrobial peptides (AMPs) are released to limit the invasive damages incurred by the bacteria. In response, phagocytic cells engulf the organisms; however, as described previously, leptospires are capable of replicating and surviving in phagolysosomes. The host immune system continuously releases excessive amounts of cytokines, culminating as a destructive response instead of a beneficial one [162]. 


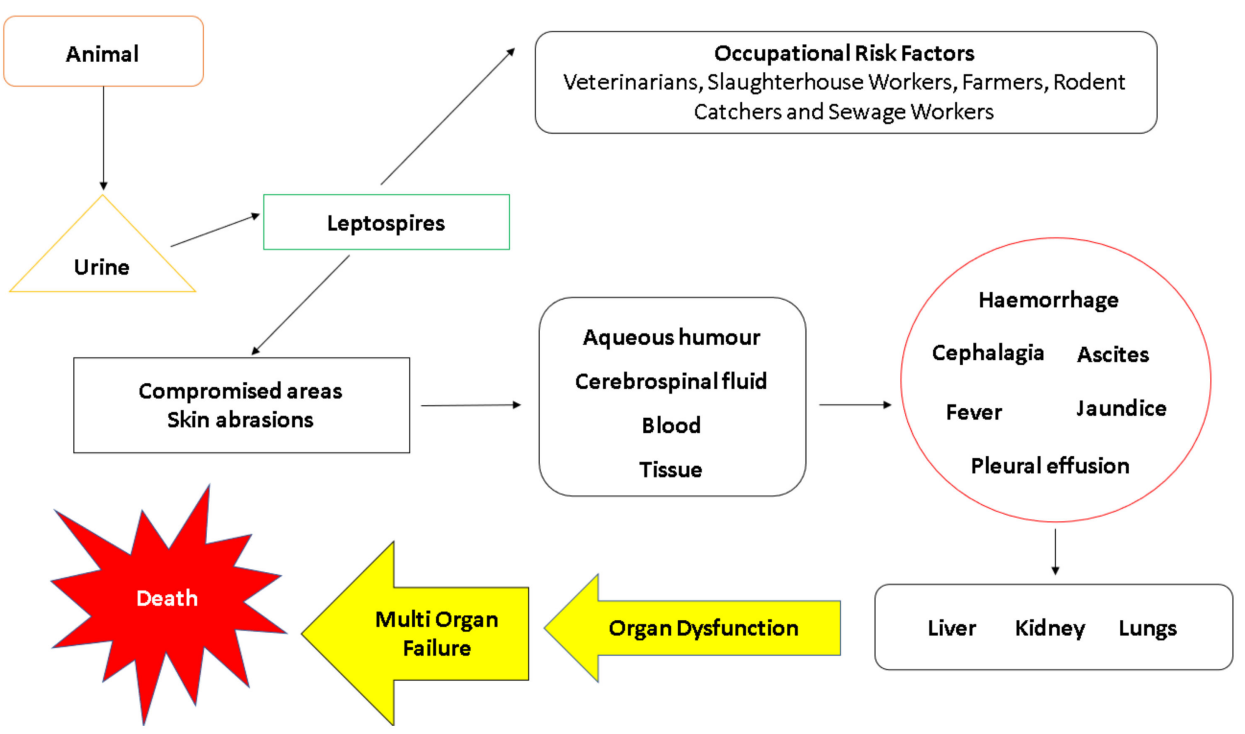

Figure 4. Summary of the transmission and pathogenesis framework in leptospirosis.

Their high motility and resistance to complement proteins are noted to be effective evasive mechanisms in leptospires [149]. Other virulence factors documented in the existing literature includes their ability to form biofilms, high stability of their outer membrane [24], active LPS biosynthesis, iron uptake, innate stress response and collagenase activity $[28,159]$. Two-Component System (TCS) proteins are also reported to be responsible for leptospiral virulence. Adhikarla et al. [163] reinforced the aforementioned statement as they found that leptospiral strains in hamster models become avirulent after deliberately disrupting two TCS genes-namely, lvrA and lvrB. The authors concluded that much of the organism's virulence stems from sophisticated signalling pathways that are yet to be unravelled. As it remains uncertain, genetic, proteomic and transcriptomic research is definitely required to further understand the progression and pathogenesis of leptospirosis.

\section{Co-Infections}

The tendency for leptospirosis to co-exist with other diseases presents as a diagnostic and therapeutic challenge for many. This creates significant amounts of difficulty in pinpointing the singular diseases, and provision of too many medications could be detrimental to a particular patient. This brief section provides an overview regarding the aforesaid challenges to acknowledge the existence of leptospiral co-infections and to establish a better understanding of their tendency to co-infect.

Dengue is often associated together with leptospirosis. Several leptospirosis/dengue co-infections have been reported in various countries, including Puerto Rico [164]. A study by Sachu et al. [165] found an association between leptospirosis/dengue co-infection with symptoms such as bleeding gums and rashes. Rainfall was also found to have a positive correlation with leptospirosis/dengue co-infection, but their results were deemed statistically insignificant. Diagnosing and treating this co-infection in the early phases can be quite challenging. as both dengue and leptospirosis evoke clinical manifestations that are similar to acute febrile illnesses. However, the actual problem lies in their combined severity; to reinforce, severe leptospirosis can lead to jaundice and multiple organ dysfunction, whilst dengue can lead to dengue haemorrhagic fever (DHF) and dengue shock syndrome (DSS) [166]. Treatment of leptospirosis is antibiotic-focused, while dengue is often treated symptomatically. However, the overlapping spectrum of clinical manifestations can easily lead to misdiagnosis, subsequently delaying provision of appropriate antibiotics and symptomatic care [165].

Zika virus (ZIKV) disease is a mosquito-borne malady that often leads to congenital abnormalities, including microcephaly [167]. Reports of leptospirosis/Zika co-infections are evident in the existing literature. Neaterour et al. [168] reported a case of leptospirosis/Zika 
co-infection without any obvious clinical picture. The patient did not have any distinct rashes (obvious picture of ZIKV infection) but ZIKV nucleic acid levels were notably increased. The authors theorized that the symptoms of ZIKV infection may be "masked" by the more virulent symptoms inflicted by leptospirosis (presenting with more obvious signs and symptoms). Biron et al. [169] found that the tendency for this co-infection to occur highly depends on geographical factors; prevalence is notably higher in returning travellers/tourists from tropical regions.

Leptospirosis/malaria is an emerging co-infection especially prevalent in the borders of Thailand and Myanmar. Fever is usually the first symptom detected in afflicted patients, with no obvious signs of leptospiral involvement. However, as the co-infection develops further, clinical pictures of leptospirosis becomes more apparent as Weil's disease, pulmonary haemorrhage and/or uveitis develops. Diagnosing the co-infection at this stage could prove to be futile due to the combined severity of both diseases. An alarming fatality rate of approximately $1-14 \%$ coincides with poor diagnosis associated with the co-infection; to reinforce, diagnosis attempts often result in negative microscopic agglutination test (MAT) results, even though the patient's serum contains high levels of anti-leptospiral IgM. To make matters worse, the emergence of multi-drug-resistant (MDR) malaria hinders therapeutic efforts, resulting in poor prognosis [170].

According to a case report by Markotić et al. [171], a Croatian soldier was suspected of suffering from leptospirosis and Hantavirus haemorrhagic fever with renal syndrome (HFRS). From his background, the soldier lives in a rodent-infested area, thereby increasing his likelihood of contracting the co-infection. Clinical pictures that were reported include fever, headache, visual difficulties, renal failure, conjunctival suffusion and petechiae. Diagnosing the patient via conventional methods is difficult as a multitude of symptoms (renal failure, pulmonary disorders and liver disorders) are quite similar. In light of that, leptospirosis was positively diagnosed via microagglutination whilst Dobrava-Belgrade orthohantavirus (DOBV) was identified as the causative agent (for HFRS) via PCR analysis. Although HFRS is classified as a noncurative disease, the severity of leptospirosis can be mitigated with proper and monitored use of antibiotics. Sunil-Chandra et al. [172] reported a similar co-infection with Puumala virus (PUUV) as the causative agent. Gamage et al. [173] also documented a fairly similar co-infection caused by Thailand virus (THAIV). Overall, the prompt identification of their role in immune responses and the ability to differentiate the two diseases are of utmost importance for the betterment of treatment.

Another common co-infection is leptospirosis with scrub typhus, especially prevalent amongst agriculture workers. The non-specific nature of the collective symptoms reported (fever, headache, myalgia and conjunctival suffusion) persists as a problem for diagnosis and therapy. As scrub typhus can be seen mostly in Asia, South Pacific and Northern Australia, it can be inferred that the co-infection is also found majorly in these areas $[174,175]$. According to a report by Watt et al. [175], difficulties in diagnosing the co-infection led to the death of an agricultural worker (due to adult respiratory distress syndrome), further highlighting the severity of leptospirosis co-infections and its worrisome trend worldwide.

\section{Clinical Manifestations}

In humans, it is well acknowledged that the symptoms seen in leptospirosis can be somewhat confusing and subtle, easily leading to diagnoses that are false negative. Lau et al. [147] documented that the mass majority of misdiagnosis in leptospirosis is largely due to the non-specific nature of the clinical manifestations seen in the disease. The initial symptoms that are documented in the existing literature includes cephalalgia, prostration, fever, haemorrhage, pleural effusion, ascites, hypertrophy, hepatomegaly and splenomegaly $[22,24,148,176,177]$. Although these manifestations are deemed to be associated with leptospirosis, they should not be exclusively denoted as confirmatory signs of the disease. The non-specific and subtle nature of these symptoms highlight the severity of leptospirosis, as many of these signs can go unnoticed by patients and physicians alike. Furthermore, this disease inflicts harm to multiple organs, possibly 
leading to interstitial nephritis, kidney lesions, uraemia, oliguria, vascular injury, jaundice, meningitis, confusion, psychosis and delirium $[22,24,148,176]$. After patients are sufficiently treated with care, they tend to experience post-recovery symptoms, most notably fatigue, headache, paresis, paralysis, ocular signs, mood swings and depression. These signs denote the persistence of leptospires in the patients, which are seemingly "camouflaged" by the host immune response. A simple graphical presentation summarizing the aforementioned manifestations is outlined in Figure 5. In pregnant women, leptospirosis can sometimes cause congenital leptospirosis, stillbirth, foetal cardiotocography changes and even foetal death [178]. Overall, the lack of classical symptoms and its tendency to exist as co-infections with other unrelated diseases highlights the importance of highly specific diagnostic measures for leptospirosis, which are discussed in the forthcoming section.

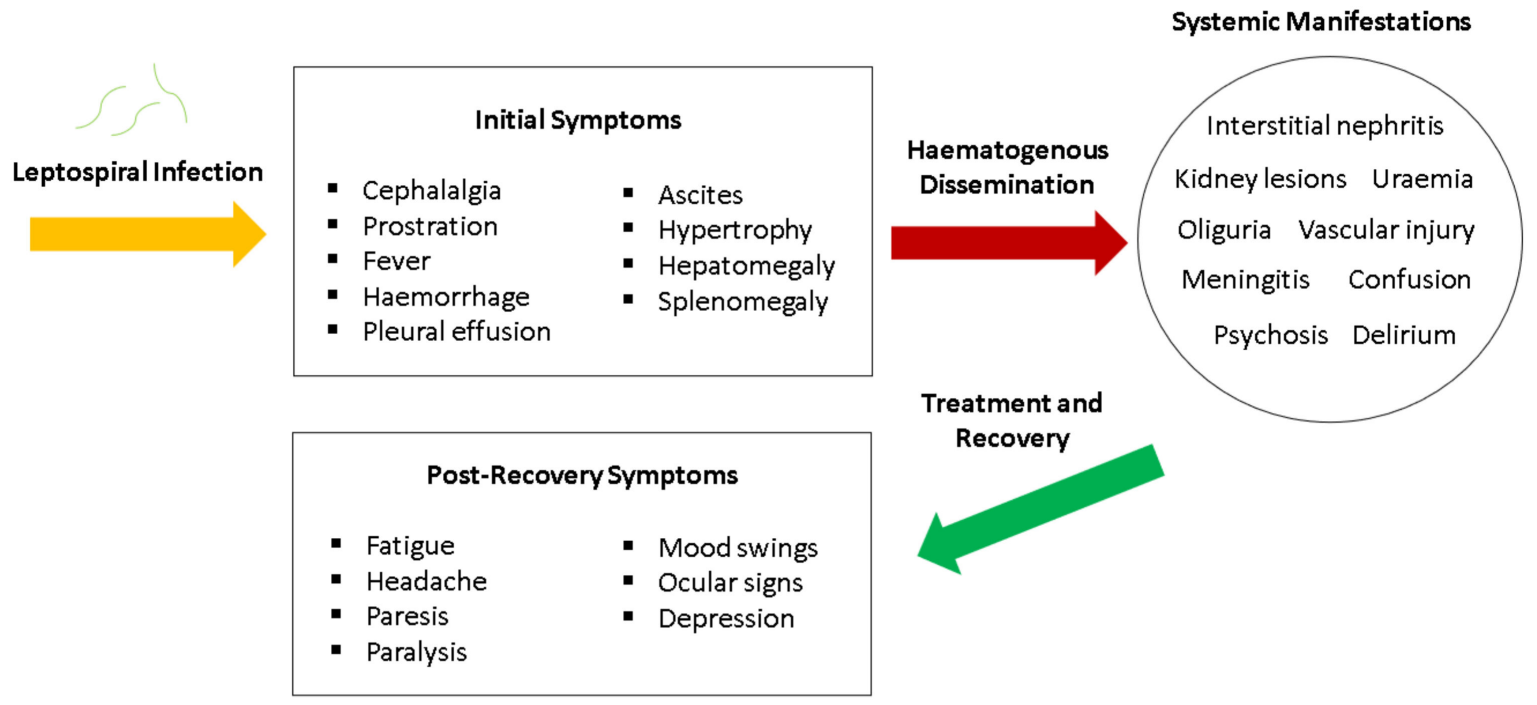

Figure 5. Summary of the clinical manifestations seen in leptospirosis.

\section{Diagnosis of Leptospirosis}

In the early stages, physicians are often unaware that their patients are infected with Leptospira. Diagnosis is only often made when clinical symptoms depicting Weil's disease, pulmonary haemorrhage, jaundice or renal failure are apparent. The differential diagnosis for these symptoms is confounding and ranges from benign viral syndromes of childhood to meningitis and sepsis $[179,180]$. Sometimes the severity also varies depending upon the individual. Few individuals may possess the antigens of the particular serovar of the Leptospira species but may not show or be void of any symptoms of the infection. Hence, the diagnosis of leptospirosis must not be done by the clinical symptoms shown by the patients but rather by laboratory diagnosis. More effective and accurate diagnostic tools have been developed in order to confirm the presence of a leptospirosis infection. The currently established diagnostic tools for leptospirosis include serological tests (microscopic agglutination test (MAT), solid phase assay, enzyme linked immuno-sorbent assay (ELISA) and indirect haemagglutination assay), direct diagnostic methods (microscopy, particularly phase contrast or dark field microscopy, histochemical staining and immunostaining), culture methods and molecular techniques such as nested polymerase chain reaction (PCR) [181]. Along with these techniques, scientists and researchers have also been developing other advanced techniques such as flow cytometry. Future advancements and refinements of the current diagnostic tools will definitely hasten the diagnosis process of leptospirosis, even in the early stages [182]. The aforementioned diagnostic techniques are discussed in detail here under. 


\subsection{Clinical Findings}

The clinical findings of leptospirosis are mostly based on the increment or decrement in the levels of enzymes, blood cells or any bodily contents. These findings allow physicians to evaluate homeostatic changes in the patients' body when it is going through leptospirosis infection [177,180]. Documented samples include blood, cerebrospinal fluid and urine [183]. Erythrocyte sedimentation rate (ESR) is typically elevated due to inflammation and white blood cell count (WBC) ranges from below average to above average. Liver function test (LFT) usually shows an elevation in amino transferase, bilirubin and alkaline phosphatase. In cases of severe leptospirosis, hyperbilirubinaemia is evident due to jaundice (causative). Manifestations may be variable from mild to severe hepatic dysfunction and hepatomegaly. The most affected liver functions are bilirubin metabolism and protein synthesis [184]. Renal function test (RFT) typically shows elevated plasma creatinine in patients with severe leptospirosis. Histological findings of Leptospira-infested kidneys include tubule-interstitial nephritis, interstitial fibrosis and tubular atrophy. Proximal tubule dysfunction and hypokalemia can also be observed in adult male workers affected with leptospirosis [79]. Urine analysis demonstrates proteinuria, pyuria, microscopic haematuria, hyaline and granular casts [185]. Lumbar puncture shows an elevated cerebrospinal fluid pressure, predominance of lymphocytes and polymorphs [186]. Peripheral blood smear typically shows peripheral leukocytosis with obvious left shift and thrombocytopenia [187].

\subsection{Serological and Indirect Diagnostic Methods}

For many years, serological diagnosis or serology has been considered to be the cornerstone in identifying leptospiral infections. Serological studies are done on serum samples extracted from individuals suspected of suffering from leptospirosis. Usually, these studies are based on the detection of specific antibodies against various leptospiral antigens. Since leptospires have a very long doubling times in culture and the culture takes weeks to grow, the diagnosis of leptospirosis mostly depends on serological results.

\subsubsection{Microscopic Agglutination Test (MAT)}

MAT has been widely used for the diagnosis of leptospirosis through detection of antibodies produced against the antigens of Leptospira serovars [188]. This technique utilizes live bacterial cultures and is routinely performed by incubating patient's serum with various serovars of Leptospira [189]. MAT titre is obtained by testing various serum dilutions with a positive serovar. A four-fold rise of MAT antibody titre is a definite evidence of Leptospira infection. Regarded as the gold standard for all diagnostic techniques, this assay has a high sensitivity and allows for the detection of group-specific antibodies $[190,191]$. In regions where leptospirosis is common, there may be a substantial proportion of the population with elevated titres of MAT. In addition to this, the serum from patients may react with a different serovar than the infected one. In case of many numbers of samples, performing MAT would be very difficult as it is a complicated test. Moreover, diagnostic laboratories are also required to have all the circulating types of Leptospira serovars, which may be costly [192]. It would not be useful during the early stages of the disease as the antibodies against the leptospires are usually not present, or if at all present, it will be at an extremely low level in the cerebrospinal fluid [180]. Hence, other diagnostic techniques have been developed that are more rapid and easier to carry out.

\subsubsection{Microsphere Immunoassay (MIA)}

Although MAT has been the gold standard and most widely used technique in the diagnosis of leptospirosis, it relies heavily on live cultures and subjective interpretation of results. This technique is also unable to clearly differentiate between the classes of anti-leptospiral antibodies. MIA (which utilizes the Luminex xMap technology) is able to positively diagnose samples from those that were previously deemed non-reactive. It is also capable of differentiating between IgM and IgG antibodies against Leptospira. The MIA test is carried out by preparing antigens from pure Leptospira cultures and preparing 
immunoassays for IgG and IgM [191]. Briefly, the technique relies on magnetic-coated polystyrene beads filled with bi-coloured fluorescent dyes in different ratios resulting in 500 distinct bead sets. Each bead set may be coated with a different antigen to allow simultaneous measurement of antibody response to up to 500 different antigens. This high throughput screening system allows processing of high numbers of patient samples per day [193]. Its speed, sensitivity and accuracy of multiple binding events measured in the same small volume have the potential to replace many diagnostics methods and deliver hundreds of analyte data simultaneously. The test has shown notable success in identifying antibody types as well as the reactivity of antigens. Additional benefits of using MIA to diagnose leptospirosis include significant cost-reduction and allows for bulk sampling against serovars at one time.

\subsubsection{Enzyme-Linked Immunosorbent Assay (ELISA)}

ELISA can also be used to diagnose leptospirosis by utilizing leptospiral-specific IgM and IgG [194] from sera of patients infected with different leptospiral serovars. According to a study by Hartman et al. [195], subjects with leptospirosis produced specific IgM and IgG antibodies that are detectable by ELISA, even with low titre of antigens in their serum. Only a few subjects had IgG agglutinins whereas all of them produced IgM agglutinins. The specificity and sensitivity of the test suggests that the ELISA anti-IgM technique is a suitable method for detecting leptospiral antibodies in sera for diagnostic and epidemiological purposes [196]. The specificity of the antisera used to prepare the conjugates was confirmed by immunodiffusion and by immunoelectrophoresis against purified human IgM and IgG immunoglobulins [197] (Figure 6). While it is indeed effective, Shekatkar et al. [198] documented that antibody levels are generally low or absent during early phases of the infection. This can be a problem in diagnostic terms, as this could easily lead to false negative diagnoses $[199,200]$.
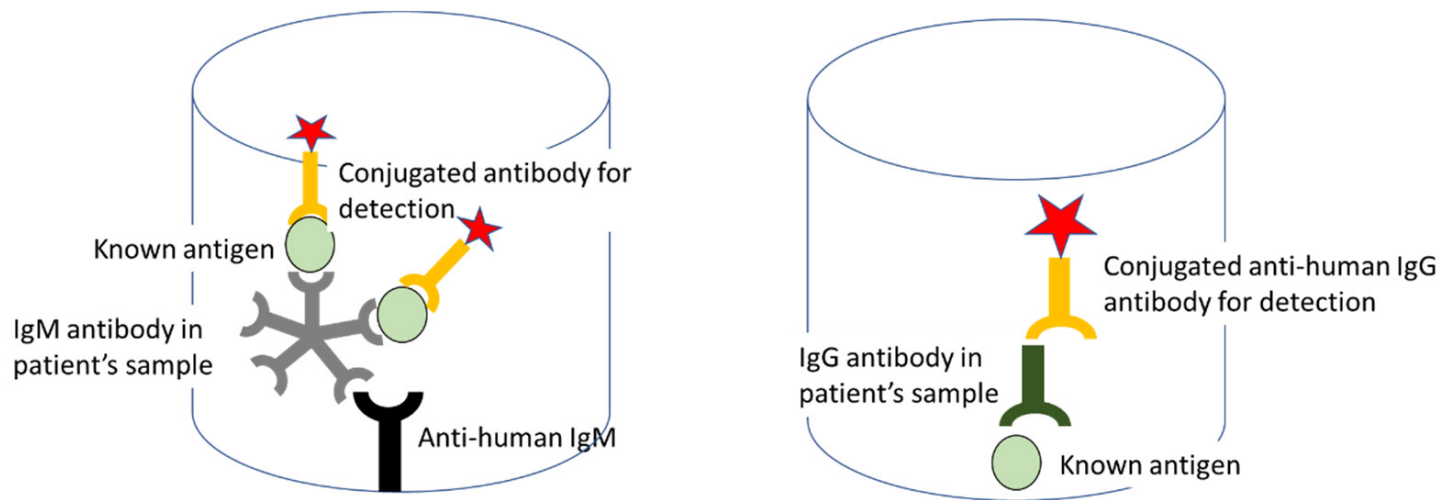

Figure 6. ELISA using IgM and IgG antibody for leptospiral diagnosis.

\subsubsection{Indirect Haemagglutination Assay (IHA)}

IHA also detects IgM and IgG produced against Leptospira antigens in the body after bacterial entry (within 4-6 days) [194]. Commercial kits for this assay are widely available in the market, following the principle as illustrated in (Figure 7). Levett and Whittington [201] documented that IHA has a diagnostic sensitivity of $92 \%$ and a specificity of $95 \%$. This assay can be utilized as an initial diagnostic tool for patients who are clinically suspected to be having acute leptospirosis. It is advantageous due to its relatively low cost and it requires no specialized equipment or any strict incubation conditions. One significant disadvantage of using IHA is that the results may not be interpretable when there is nonspecific haemagglutination [201]. Bajani et al. [202] documented that IHA is significantly less sensitive than ELISA for the diagnosis of leptospirosis. It was also found that the sensitivity of IHA is somewhat similar to that of MAT assay [181]. 


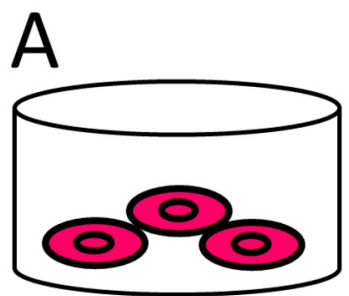

'Ag' sensitized $\mathrm{RBC}$

B

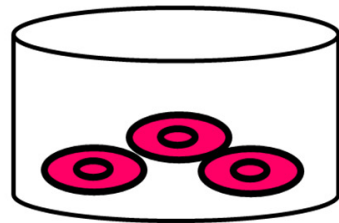

'Ag' sensitized RBC

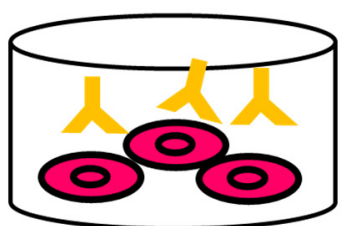

Serum from infection positive patient

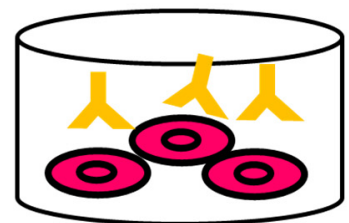

Serum from infection negative patient

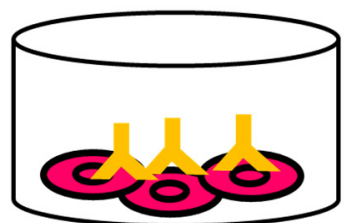

Agglutination of RBC

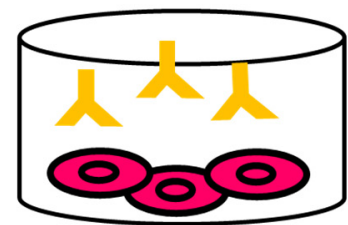

No Agglutination of RBC

Figure 7. Illustration depicting the principles of IHA to detect leptospires (A) positive reaction and (B) negative reaction.

\subsubsection{Dipstick Assay}

Dipstick assay is an easy and robust technique that allows for rapid screening and diagnosis of patients suspected of having leptospirosis. The LEPTO dipstick test is a rapid field test for leptospirosis that does not require special laboratory equipment or welltrained personnel $[203,204]$. This assay (tested under different epidemiological and clinical conditions) demonstrated high sensitivity, specificity and predictive values. The dipstick assay, as described by Hatta et al. [203], assesses the samples using a dipstick which contains two horizontal bands-namely, the lower band consisting of broadly reactive specific antigens and the upper band which acts as an internal control as it consists of antihuman IgM antibodies (Figure 8). Bound IgM antibodies are detected in non-enzymatic reactions with a stabilized anti-human IgM dye conjugate and the sensitivity is comparable to IgM-ELISA [181].

\subsubsection{Flow Cytometry (FCM)}

The purpose of using FCM for diagnosing leptospirosis is due to its high sensitivity towards the size and shape of leptospires [205]. The scattering parameters-namely, forward scatter (FSC) and side scatter (SSC) - play a pivotal role for this technique. FSC is associated with the cell size and optical refraction index of the outer membrane, whilst SSC is related to the bacterial granularity [206]. Diagnosis of leptospirosis can be done by assessing the light scattering patterns after carrying out the agglutination reaction between the antigen and antibody of a specific serovar type in Leptospira. Analysis is possible because recent flow cytometers have a resolution capacity to detect and observe particles that are less than $0.5 \mu \mathrm{m}$ diameter [207]. These analysers are usually equipped with an excitation light source that emits laser beam from it at a particular wavelength, an amplifier to amplify the signal and detectors such as a photodiode (for FSC) or a photomultiplier (for SSC) to detect the amplified signal [208]. According to Yitzhaki et al. [209], FCM is more efficient, rapid (can be completed within $1.5 \mathrm{~h}$ ), specific and sensitive for the diagnosis of leptospirosis, especially in identifying specific serovars during the acute phase of the disease. 

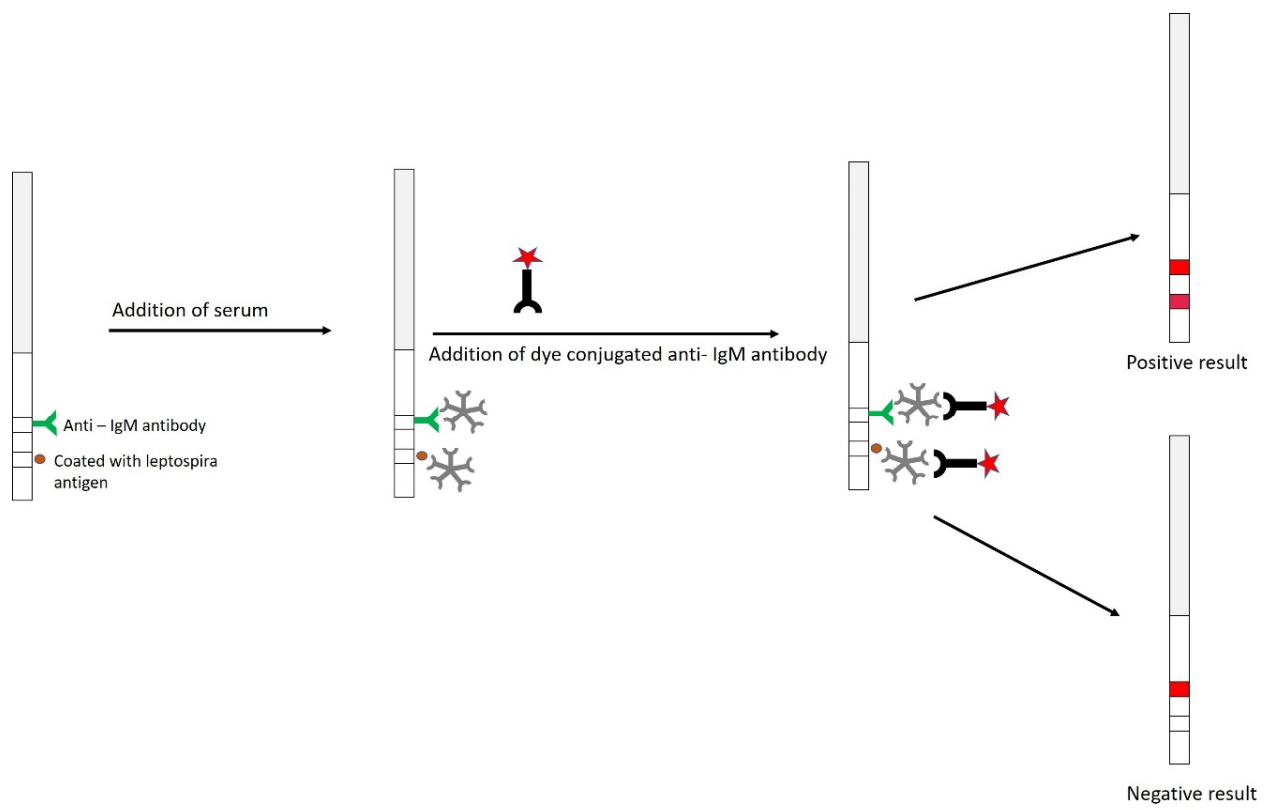

Figure 8. Illustration depicting dipstick assay.

\subsection{Direct Diagnostic Methods}

\subsubsection{Microscopy Techniques}

This technique is particularly useful for observing leptospires in culture, particularly when they are present in large numbers, and also for observing the agglutination formed via MAT (microscopic agglutination test). Leptospires present in patient samples can be concentrated using centrifugation. One of the disadvantages in using microscopy for diagnosis is that the direct microscopic observation of leptospires in urine (leptouria test) may have a low specificity since the presence of fibrin and protein in the urine samples can be mistaken for leptospires [180]. As such, false diagnosis is possible. Phase contrast microscopy is useful in observing transparent, colourless and/or unstained specimens which can be referred to as "phase objects". Even though phase contrast microscopy is useful for visualizing leptospires in the laboratory, its viability in the diagnostic laboratory is clouded by its technical limitations in thick suspensions and its optical characteristics [210] Leptospires can be easily detected under dark field microscopy as thin, coiled, motile organisms in blood and urine samples of patients with leptospirosis. However, the positivity of dark field microscopy decreases from $100 \%$ to $90.9 \%$ as the duration of infection increases for more than one week [211]. Another disadvantage of this technique is that both false positive and false negative diagnosis can be easily made, even by experienced technicians.

\subsubsection{Staining Techniques}

A variety of histopathological stains are used for the detection of leptospires in clinical specimens. Although silver stains have been documented to be of use in the literature [212], the Warthin-Starry stain is widely in use now. Azizi et al. [213] commented that histopathological stains (including Warthin-Starry stain) can sometimes confer false negative results, as the leptospirosis burden in tissue biopsies (such as kidneys) may not be significant. Besides histopathological stains, immunohistochemical assay and immunoglobulin fluorescent staining are also documented to be useful diagnostic tools for leptospirosis. Immunoglobulin staining is usually done on tissues with positive immunoreactivity towards leptospiral antigens [214]. The technique revolves around the use of enzymatic or metallic labels on secondary antibodies. Phosphatase, peroxidase or metallic gold-labelled antibody can be used in a variety of formats to stain leptospires in clinical specimens [215]. This technique has the advantage of being useful with formalin-fixed tissue. It can also be used to detect leptospires even when their numbers are significantly low, or when there 
are materials that precludes the use of dark field microscopy. However, immunostaining requires a primary antibody that is specific for the serovar being sought [180]. Too many serovar varieties in a pool would dilute any one, so high-titre antisera conjugates are required. In other words, it may be not be advantageous in early infections. This is not widely used as a primary diagnostic tool in recent studies.

\subsubsection{Culture Technique}

In this method of diagnosis, samples from a suspected patient, usually urine and/or blood sample, are taken and streaked onto a culture flask containing fluid media (generally used for primary culture). Oleic acid-albumin media of EMJH is the most commonly used media for this purpose. It is composed of a basic medium which consists of ammonium chloride, thiamine, disodium phosphate and monopotassium phosphate as well as various enrichment factors including Tween 80 and albumin [216]. Antibiotics such as rifampicin, neomycin, actidione can be added to the media for selective isolation of bacteria from contaminated samples [217]. Advantageously, leptospires can be cultured from blood or cerebrospinal fluid samples during the acute phases of the infection (lasts for about 10 days). Even though this method provides highly accurate results, it is a tedious and long process. This is because leptospires take a very long time to divide (doubling time is estimated to be 6-8 h) and the whole culture can take almost 3 months to grow. As leptospires are highly infectious organisms, they need to be handled with utmost care, even by experienced personnel. Therefore, there may be risk of laboratory-acquired infections with this technique [180].

\subsubsection{Polymerase Chain Reaction (PCR)}

PCR is used to amplify DNA content as an essential pre-requisite for sample analysis. It is especially important when the DNA content in samples is deemed to be low or undetectable. With PCR, Leptospira can easily be detected from urine samples or blood samples during the early stages of the disease [218]. During acute leptospirosis, the antibody titre may not be high enough for accurate serological diagnosis. A prime advantage of using PCR is that results are generated very quickly, as compared to conventional techniques like culture [219-221]. With specially designed primers, a variety of leptospiral targets can be amplified for diagnosing the disease-namely, 16S ribosomal RNA, various pathogenic wild-type genes and mutated genes. Standard PCR procedures require the subsequent use of agarose gel electrophoresis to detect target leptospiral genes [222]. However, real-time PCR (RT-PCR) is capable of providing diagnoses results immediately after the DNA content is amplified. According to Merien et al. [223], RT-PCR is highly sensitive and specific, providing accurate results in the long run. One of the major drawbacks of RT-PCR for diagnosing leptospirosis is that the primers may sometimes bind to a non-specific site, leading to false positive results. Hence, it is recommended that more than one technique should be used to increase the diagnostic sensitivity and specificity. This can be performed by developing real-time multiplex PCR assays. Multiplex PCR is done by using two sets of primers instead of one in order to increase the specificity of DNA binding and amplification [88]. The use of more than one target may be important to distinguish between true and false-positive PCR results. Nested PCR also helps in detecting more specific and sensitive DNA sites using additional sets of primers [224-226].

PCR may also prove to be useful when diagnostic resources are limited or scarce. Conventional diagnostic techniques such as culture can be useful, but most of its resources (if not all) are not available in most countries [227]. As current diagnostic trends for leptospirosis strongly suggest the use of both serological and molecular techniques for heightened accuracy, the combinatorial use of PCR and ELISA (in place of the cumbersome gold standard MAT) for early diagnosis is a powerful alternative in resource-poor countries [228], highlighting the significance of combinatorial techniques in diagnoses. Besides that, Koizumi et al. [229] developed a revolutionary loop-mediated isothermal amplification (LAMP) technique to detect a 16S rRNA gene ( $r r s$ ) that are typically found in 
urines of patients infected with pathogenic leptospires. This technique also caters well for developing countries as it is cost-effective, rapid and highly accurate in producing consistent results. To summarize, the value of PCR in clinical diagnosis is unparalleled. Further upgrades and advancements of current PCR techniques (as well as other revolutionary techniques such as LAMP) could expand these techniques as routine tests for leptospirosis.

\section{Epidemiological and Transmission Patterns of Leptospirosis: Future Concerns}

Although the risk factors and transmission of leptospirosis have already been elaborated in previous sections, the erratic epidemiological and transmission pattern of the disease is slowly culminating into a global concern, and is thus separately highlighted here. It is evident that various epidemiological characteristics coincides with higher prevalence of leptospirosis cases. Blasdell et al. [230] suggested that urbanization potentiates the transmission and circulation of Leptospira spp., resulting in substantial public health crisis as the "possibility" for leptospirosis to occur in urban areas are typically underestimated. Due to various factors such as overcrowding and contact with animals [8,9], leptospirosis is especially prevalent in rural areas, such as Senegal in West Africa [231]. Nozmi et al. [232] also found that a rural community in Malaysia has significantly low knowledge, attitude and practice (KAP) elements towards leptospirosis, coinciding with high prevalence of leptospirosis cases. Places with high rates of natural disasters (such as major floods) [10], multiple records of international travels [22] and highly engaged with recreational activities such as water-based sports [24] also coincides with high cases of leptospirosis.

The transmission patterns of leptospirosis outbreaks vary by a huge margin. As reviewed by Haake and Levett [134], cases of leptospirosis endemics are especially prevalent in tropical areas (peak incidence at high temperatures), often culminating to large, isolated epidemics and outbreaks following rainfalls and flash floods. The disease is highly seasonal-dependent, as temperature is a limiting factor for the survival of leptospires. This highlights the tendency for leptospirosis cases to increase dramatically with certain seasons, climate changes and natural disasters [10]. Besides that, a systematic review by Bierque et al. [233] highlighted the significance of biofilm formation in the transmission of leptospires. To reinforce, pathogenic leptospires are capable of surviving in biofilms in natura (even in nutrient-free settings), and their tolerance towards antibiotics can be increased by 5-fold. From this, it is evident that biofilm formation significantly favours leptospiral survival and persistence, ultimately potentiating their transmission rates. As such, sustained outbreaks are common $[10,12]$, even extending to broad geographical regions. As the epidemiological and transmission patterns of leptospirosis remain unprecedented to many, various global concerns may arise in the near future, possibly leading to pandemics and more deaths. This further highlights the importance of epidemiological data in an effort to combat infectious diseases worldwide, a feat that is not possible without the collaborative efforts of many.

\section{Conclusions}

From this review, it is clear that various risk factors increase the likelihood for one person to be inflicted with leptospirosis, but these factors can be unpredictable at times. Pathogenic leptospires attain their virulence due to the presence of various proteins (especially outer membrane proteins), allowing them to transmit and cause diseases easily. The unrelenting nature of Leptospira leads to a deadly combination of clinical symptoms, and often times these treatments may be insufficient. The recent emergence of leptospiral co-infections with unrelated diseases such as HFRS, dengue and malaria highlight the culminating severity of leptospirosis. Diagnosis of leptospirosis has always been difficult.

Funding: The funding for this review work was supported by Universiti Putra Malaysia High Impact Grant 'Geran Berimpak' (Grant no. 9674600).

Institutional Review Board Statement: Not applicable.

Informed Consent Statement: Not applicable. 
Data Availability Statement: No new data were created or analyzed in this study. Data sharing is not applicable to this article.

Conflicts of Interest: The authors declare no conflict of interest

\section{References}

1. Altizer, S.; Bartel, R.; Han, B.A. Animal migration and infectious disease risk. Science 2011, 331, 296-302. [CrossRef]

2. Yang, S.; Wu, J.; Ding, C.; Cui, Y.; Zhou, Y.; Li, Y.; Deng, M.; Wang, C.; Xu, K.; Ren, J.; et al. Epidemiological features of and changes in incidence of infectious diseases in China in the first decade after the SARS outbreak: An observational trend study. Lancet Infect. Dis. 2017, 17, 716-725. [CrossRef]

3. Ostfeld, R.S.; Keesing, F. The function of biodiversity in the ecology of vector-borne zoonotic diseases. Can. J. Zool. 2000, 2061-2078. [CrossRef]

4. Jones, K.E.; Patel, N.G.; Levy, M.A.; Storeygard, A.; Balk, D.; Gittleman, J.L.; Daszak, P. Global trends in emerging infectious diseases. Nature 2008, 451, 990-993. [CrossRef]

5. Chatterjee, P.; Bhaumik, S.; Chauhan, A.S.; Kakkar, M. Protocol for developing a Database of Zoonotic disease Research in India (DoZooRI). BMJ Open 2017, 7, e017825:1-e017825:4. [CrossRef]

6. Noguchi, H. SpirochÆta icterohÆmorrhagiÆ in american wild rats and its relation to the japanese and european strains. First paper. J. Exp. Med. 1917, 25, 755-763. [CrossRef]

7. Mayer, F.Q.; Dos Reis, E.M.; Bezerra, A.V.A.; Cerva, C.; Rosa, J.; Cibulski, S.P.; Lima, F.E.S.; Pacheco, S.M.; Rodrigues, R.O. Pathogenic Leptospira spp. in bats: Molecular investigation in Southern Brazil. Comp. Immunol. Microbiol. Infect. Dis. 2017, 52, 14-18. [CrossRef]

8. WHO. Leptospirosis Burden Epidemiology Reference Group (LERG). Available online: https://www.who.int/zoonoses/ diseases/lerg/en/ (accessed on 3 October 2020).

9. Londe, L.D.; da Conceição, R.S.; Bernardes, T.; de Assis Dias, M.C. Flood-related leptospirosis outbreaks in Brazil: Perspectives for a joint monitoring by health services and disaster monitoring centers. Nat. Hazards 2008, 84, 1419-1435. [CrossRef]

10. Mohd Radi, M.F.; Hashim, J.H.; Jaafar, M.H.; Hod, R.; Ahmad, N.; Nawi, A.M.; Baloch, G.M.; Ismail, R.; Ayub, N.I.F. Leptospirosis outbreak after the 2014 major flooding event in Kelantan, Malaysia: A spatial-temporal analysis. Am. J. Trop. Med. Hyg. 2018, 98, 1281-1295. [CrossRef]

11. Pappas, G.; Papadimitriou, P.; Siozopoulou, V.; Christou, L.; Akritidis, N. The globalization of leptospirosis: Worldwide incidence trends. Int. J. Infect. Dis. 2008, 12, 351-357. [CrossRef]

12. Dierks, J.; Servies, T.; Do, T. A Study on the Leptospirosis Outbreak Among US Marine Trainees in Okinawa, Japan. Mil. Med. 2018, 183, e208-e212. [CrossRef]

13. Jorge, S.; Schuch, R.A.; de Oliveira, N.R.; da Cunha, C.E.P.; Gomes, C.K.; Oliveira, T.L.; Rizzi, C.; Qadan, A.F.; Pacce, V.D.; Coelho Recuero, A.L.; et al. Human and animal leptospirosis in Southern Brazil: A five-year retrospective study. Travel Med. Infect. Dis. 2017, 18, 46-52. [CrossRef]

14. Kurilung, A.; Chanchaithong, P.; Lugsomya, K.; Niyomtham, W.; Wuthiekanun, V.; Prapasarakul, N. Molecular detection and isolation of pathogenic Leptospira from asymptomatic humans, domestic animals and water sources in Nan province, a rural area of Thailand. Res. Vet. Sci. 2017, 115, 146-154. [CrossRef]

15. Tilahun, Z.; Reta, D.; Simenew, K. Global Epidemiological Overview of Leptospirosis. Int. J. Microbiol. Res. 2013, 4, 9-15. [CrossRef]

16. Vitale, M.; Agnello, S.; Chetta, M.; Amato, B.; Vitale, G.; Bella, C.D.; Vicari, D.; Presti, V.D.M.L. Human leptospirosis cases in Palermo Italy. The role of rodents and climate. J. Infect. Public Health 2018, 11, 209-214. [CrossRef]

17. Ijaz, M.; Abbas, S.N.; Farooqi, S.H.; Aqib, A.I.; Anwar, G.A.; Rehman, A.; Ali, M.M.; Mehmood, K.; Khan, A. Sero-epidemiology and hemato-biochemical study of bovine leptospirosis in flood affected zone of Pakistan. Acta Trop. 2018, 177, 51-57. [CrossRef]

18. Tomari, K.; Toyokawa, T.; Takahashi, T.; Kakita, T.; Okano, S.; Kyan, H.; Tonegawa, N.; Okawa, T.; Matsuoka, T.; Matsumora, T. Childhood leptospirosis in an industrialized country: Population-based study in Okinawa, Japan. Plos Negl. Trop. Dis. 2018, 12, e0006294:1-e0006294:10. [CrossRef]

19. Dos Santos, L.F.; Guimarães, M.F.; de Souza, G.O.; da Silva, I.W.G.; Santos, J.R.; Azevedo, S.S.; Labruna, M.B.; Heinemann, M.B.; Horta, M.C. Seroepidemiological survey on Leptospira spp. infection in wild and domestic mammals in two distinct areas of the semi-arid region of northeastern Brazil. Trop. Anim. Health Prod. 2017, 49, 1715-1722. [CrossRef]

20. Prajapati, A.; Kushwaha, A.; Chayanika, D.; Subhashree, N.; Varsha, P.; Marcia, A.; Lahari, L.; Shankar, S.; Patel, N. A Review on Bovine Leptospirosis with Special Reference to Seroprevalence in India. Int. J. Curr. Microbiol. Appl. Sci. 2018, 7, 1813-1820. [CrossRef]

21. Naotunna, C.; Agampodi, S.B.; Agampodi, T.C. Etiological agents causing leptospirosis in Sri Lanka: A review. Asian Pac. J. Trop. Med. 2016, 9, 390-394. [CrossRef]

22. Hartskeerl, R.A.; Collares-Pereira, M.; Ellis, W.A. Emergence, control and re-emerging leptospirosis: Dynamics of infection in the changing world. Clin. Microbiol. Infect. 2011, 17, 494-501. [CrossRef]

23. Buchanan, G. Spirochaetal Jaundice. BMJ 1927, 1, 844. [CrossRef]

24. Johnson, D.I. Leptospira spp. In Bacterial Pathogens and Their Virulence Factors; Johnson, D.I., Ed.; Springer International Publishing: Cham, Switzerland, 2018; pp. 289-294. 
25. Abela-Ridder, B.; Sikkema, R.; Hartskeerl, R.A. Estimating the burden of human leptospirosis. Int. J. Antimicrob. Agents 2010, 36, S5-S7. [CrossRef]

26. Report of the Second Meeting of the Leptospirosis Burden Epidemiology Reference Group. 2011. Available online: https:/ /apps.who.int/iris/bitstream/handle/10665/44588/9789241501521_eng.pdf;jsessionid=B3BABBEB195C52A6FAA5 DF9BEA06CA20? sequence $=1$ (accessed on 3 October 2020).

27. Mohammed, H.; Nozha, C.; Hakim, K.; Abdelaziz, F. Leptospira: Morphology, Classification and Pathogenesis. J. Bacteriol. Parasitol. 2011, 2, 1000120:1-1000120:4. [CrossRef]

28. Bulach, D.; Adler, B. Leptospiral genomics and pathogenesis. In Current Topics in Microbiology and Immunology; Adler, B., Ed.; Springer International Publishing: Cham, Switzerland, 2018; pp. 189-214.

29. Benacer, D.; Who, P.Y.; Zain, S.N.M.; Amran, F.; Thong, K.L. Pathogenic and saprophytic Leptospira species in water and soils from selected urban sites in peninsular Malaysia. Microbes Environ. 2013, 28, 135-140. [CrossRef]

30. Hovind-Hougen, K. Leptospiraceae, a new family to include Leptospira Noguchi 1917 and Leptonema gen. nov. Int. J. Syst. Bacteriol. 1979, 29, 245-251. [CrossRef]

31. Jackson, K.M.; Schwartz, C.; Wachter, J.; Rosa, P.A.; Stewart, P.E. A widely conserved bacterial cytoskeletal component influences unique helical shape and motility of the spirochete Leptospira biflexa. Mol. Microbiol. 2018, 108, 77-89. [CrossRef]

32. Hovind-Hougen, K.; Ellis, W.A.; Birch-Andersen, A. Leptospira parva sp.nov.: Some morphological and biological characters. Zent. Für Bakteriol. Mikrobiol. Und Hyg. Abt. 1 Orig. A 1981, 250, 343-354. [CrossRef]

33. Chaiwattanarungruengpaisan, S.; Suwanpakdee, S.; Sangkachai, N.; Chamsai, T.; Taruyanon, K.; Thongdee, M. Potentially Pathogenic Leptospira Species Isolated from a Waterfall in Thailand. Jpn. J. Infect. Dis. 2018, 71, 65-67. [CrossRef]

34. Yasuda, P.H.; Steigerwalt, A.G.; Sulzer, K.R.; Kaufmann, A.F.; Rogers, F.; Brenner, D.J. Deoxyribonucleic Acid Relatedness between Serogroups and Serovars in the Family Leptospiraceae with Proposals for Seven New Leptospira Species. Int. J. Syst. Bacteriol. 1987, 37, 407-415. [CrossRef]

35. Cameron, C.E. Leptospiral Structure, Physiology, and Metabolism. In Current Topics in Microbiology and Immunology; Adler, B., Ed.; Springer: Heidelberg, Germany, 2015; pp. 21-41.

36. Asensio-Sánchez, V.M.; Haro-Álvarez, B.; Herreras, J.; Martín-Prieto, A. Unusual ocular clinical manifestation of leptospirosis. Arch. De La Soc. Española De Oftalmol. (Engl. Ed.) 2018, 93, 342-346. [CrossRef]

37. Rathinam, S.R. Ocular leptospirosis. Curr. Opin. Ophthalmol. 2002, 13, 381-386. [CrossRef]

38. Jutras, B.L.; Scott, M.; Parry, B.; Biboy, J.; Gray, J.; Vollmer, W.; Jacobs-Wagner, C. Lyme disease and relapsing fever Borrelia elongate through zones of peptidoglycan synthesis that mark division sites of daughter cells. Proc. Natl. Acad. Sci. USA 2016, 113, 9162-9170. [CrossRef]

39. Picardeau, M. Virulence of the zoonotic agent of leptospirosis: Still terra incognita? Nat. Rev. Microbiol. 2017, 15, 297-307. [CrossRef]

40. Murray, G.L.; Srikram, A.; Henry, R.; Hartskeerl, R.A.; Sermswan, R.W.; Adler, B. Mutations affecting Leptospira interrogans lipopolysaccharide attenuate virulence. Mol. Microbiol. 2010, 78, 701-709. [CrossRef]

41. Fraga, T.R.; Barbosa, A.S.; Isaac, L. Leptospirosis: Aspects of innate immunity, immunopathogenesis and immune evasion from the complement system. Scand. J. Immunol. 2011, 73, 408-419. [CrossRef]

42. Morton, H.E.; Anderson, T.F. The Morphology of Leptospira icterohemorrhagiae and L. canicola as Revealed by the Electron Microscope. J. Bacteriol. 1943, 45, 143-146. [CrossRef]

43. Anderson, D.L.; Johnson, R.C. Electron Microscopy of Immune Disruption of Leptospires: Action of Complement and Lysozyme. J. Bacteriol. 1968, 95, 2293-2309. [CrossRef]

44. Haake, D.A.; Matsunaga, J. Leptospira: A spirochaete with a hybrid outer membrane. Mol. Microbiol. 2010, 77, 805-814. [CrossRef]

45. DiRienzo, J.M.; Nakamura, K.; Inouye, M. The Outer Membrane Proteins of Gram-Negative Bacteria: Biosynthesis, Assembly, and Functions. Annu. Rev. Biochem. 1978, 47, 481-532. [CrossRef]

46. Cullen, P.A.; Haake, D.A.; Adler, B. Outer membrane proteins of pathogenic spirochetes. Fems Microbiol. Rev. 2004, 28, 291-318. [CrossRef]

47. Yang, C.W.; Wu, M.S.; Pan, M.J.; Hsieh, W.J.; Vandewalle, A.; Huang, C.C. The leptospira outer membrane protein LipL32 induces tubulointerstitial nephritis-mediated gene expression in mouse proximal tubule cells. J. Am. Soc. Nephrol. 2002, 13, 2037-2045. [CrossRef]

48. Werts, C.; Tapping, R.I.; Mathison, J.C.; Chuang, T.H.; Kravchenko, V.; Saint Girons, I.; Haake, D.A.; Godowski, P.J.; Hayashi, F.; Ozinsky, A.; et al. Leptospiral lipopolysaccharide activates cells through a TLR2-dependent mechanism. Nat. Immunol. 2001, 2, 346-352. [CrossRef]

49. Lin, Y.P.; Raman, R.; Sharma, Y.; Chang, Y.F. Calcium binds to leptospiral immunoglobulin-like protein, LigB, and modulates fibronectin binding. J. Biol. Chem. 2008, 283, 25140-25149. [CrossRef]

50. Stevenson, B.; Choy, H.A.; Pinne, M.; Rotondi, M.L.; Miller, M.C.; DeMoll, E.; Kraiczy, P.; Cooley, A.E.; Creamer, T.P.; Suchard, M.A.; et al. Leptospira interrogans Endostatin-Like Outer Membrane Proteins Bind Host Fibronectin, Laminin and Regulators of Complement. PLoS ONE 2007, 2, e1188:1-e1188:11. [CrossRef]

51. Matsunaga, J.; Barocchi, M.A.; Croda, J.; Young, T.A.; Sanchez, Y.; Siqueira, I.; Bolin, C.A.; Reis, M.G.; Riley, L.W.; Haake, D.A.; et al. Pathogenic Leptospira species express surface-exposed proteins belonging to the bacterial immunoglobulin superfamily. Mol. Microbiol. 2003, 49, 929-946. [CrossRef] 
52. Ristow, P.; Bourhy, P.; da Cruz McBride, F.W.; Figueira, C.P.; Huerre, M.; Ave, P.; Saint Girons, I.; Ko, A.I.; Picardeau, M. The OmpA-Like Protein Loa22 Is Essential for Leptospiral Virulence. PLos Pathog. 2007, 3, e97:1-e97:10. [CrossRef]

53. Auran, N.E.; Johnson, R.C.; Ritzi, D.M. Isolation of the outer sheath of Leptospira and its immunogenic properties in hamsters. Infect. Immun. 1972, 5, 968-975. [CrossRef]

54. Brown, J.A.; LeFebvre, R.B.; Pan, M.J. Protein and antigen profiles of prevalent serovars of Leptospira interrogans. Infect. Immun. 1991, 59, 1772-1777. [CrossRef]

55. Kida, H.; Watanabe, H.; Yamamoto, S.; Yanagawa, R. Immunological and morphological analysis of sodium dodecyl sulfate extract of Leptospira. Zentralbl. Bakteriol. Orig. A 1976, 236, 328-335.

56. Nunes-Edwards, P.L.; Thiermann, A.B.; Bassford, P.J.; Stamm, L.V. Identification and characterization of the protein antigens of Leptospira interrogans serovar hardjo. Infect. Immun. 1985, 48, 492-497. [CrossRef] [PubMed]

57. Haake, D.A.; Matsunaga, J. Characterization of the leptospiral outer membrane and description of three novel leptospiral membrane proteins. Infect. Immun. 2002, 70, 4936-4945. [CrossRef] [PubMed]

58. Wolff, D.G.; Castiblanco-Valencia, M.M.; Abe, C.M.; Monaris, D.; Morais, Z.M.; Souza, G.O.; Barbosa, A.S. Interaction of Leptospira elongation factor Tu with plasminogen and complement factor $\mathrm{H}$ : A metabolic leptospiral protein with moonlighting activities. PLoS ONE 2013, 8, e81818. [CrossRef]

59. Guerreiro, H.; Croda, J.; Flannery, B.; Mazel, M.; Matsunaga, J.; Reis, M.G.; Haake, D.A. Leptospiral proteins recognized during the humoral immune response to leptospirosis in humans. Infect. Immun. 2001, 69, 4958-4968. [CrossRef] [PubMed]

60. Fernandes, L.G.; Vieira, M.L.; Kirchgatter, K.; Alves, I.J.; de Morais, Z.M.; Vasconcellos, S.A.; Nascimento, A.L. OmpL1 is an extracellular matrix-and plasminogen-interacting protein of Leptospira spp. Infect. Immun. 2012, 80, 3679-3692. [CrossRef] [PubMed]

61. Pinne, M.; Choy, H.A.; Haake, D.A. The OmpL37 surface-exposed protein is expressed by pathogenic Leptospira during infection and binds skin and vascular elastin. PLoS Negl Trop Dis. 2010, 4, e815. [CrossRef]

62. Pinne, M.; Haake, D.A. A comprehensive approach to identification of surface-exposed, outer membrane-spanning proteins of Leptospira interrogans. PLoS ONE 2009, 4, e6071. [CrossRef]

63. Hsieh, W.J.; Chang, Y.F.; Chen, C.S.; Pan, M.J. Omp52 is a growth-phase-regulated outer membrane protein of Leptospira santarosai serovar Shermani. FEMS Microbiol. Lett. 2005, 243, 339-345. [CrossRef]

64. Giuseppe, P.O.; Neves, F.O.; Nascimento, A.L.T.; Guimarães, B.G. The leptospiral antigen Lp49 is a two-domain protein with putative protein binding function. J. Struct. Biol. 2008, 163, 53-60. [CrossRef]

65. Anandachitra, M.; Jayakumar, V.; Manohar, B.M. Detection and Sequence analysis of Lig B and LSA 21 genes of leptospires fields isolates. Asian J. Microbiol. 2011, 13, 475-479.

66. Vieira, M.L.; de Morais, Z.M.; Gonçales, A.P.; Romero, E.C.; Vasconcellos, S.A.; Nascimento, A.L. Lsa63, a newly identified surface protein of Leptospira interrogans binds laminin and collagen IV. J. Infect. 2010, 60, 52-64. [CrossRef] [PubMed]

67. Domingos, R.F.; Vieira, M.L.; Romero, E.C.; Gonçales, A.P.; de Morais, Z.M.; Vasconcellos, S.A.; Nascimento, A.L. Features of two proteins of Leptospira interrogans with potential role in host-pathogen interactions. BMC Microbiol. 2012, 12, 1-16. [CrossRef] [PubMed]

68. Eshghi, A.; Pappalardo, E.; Hester, S.; Thomas, B.; Pretre, G.; Picardeau, M. Pathogenic Leptospira interrogans exoproteins are primarily involved in heterotrophic processes. Infect. Immun. 2015, 83, 3061-3073. [CrossRef] [PubMed]

69. Grassmann, A.A.; Kremer, F.S.; dos Santos, J.C.; Souza, J.D.; Pinto, L.D.S.; McBride, A.J.A. Discovery of novel leptospirosis vaccine candidates using reverse and structural vaccinology. Front. Immunol. 2017, 8, 463. [CrossRef]

70. Lin, M.H.; Chang, Y.C.; Hsiao, C.D.; Huang, S.H.; Wang, M.S.; Ko, Y.C.; Sun, Y.J. LipL41, a hemin binding protein from Leptospira santarosai serovar Shermani. PLoS ONE 2013, 8, e83246. [CrossRef]

71. Haake, D.A.; Zückert, W.R. The leptospiral outer membrane. Curr. Top. Microbiol. Immunol. 2015, 387, $187-221$.

72. Sasaki, Y.; Kawamoto, A.; Tahara, H.; Kasuga, K.; Sato, R.; Ohnishi, M.; Nakamura, S.; Koizumi, N. Leptospiral flagellar sheath protein FcpA interacts with FlaA2 and FlaB1 in Leptospira biflexa. PLoS ONE 2018, 13, e0194923. [CrossRef]

73. Asuthkar, S.; Velineni, S.; Stadlmann, J.; Altmann, F.; Sritharan, M. Expression and characterization of an iron-regulated hemin-binding protein, $\mathrm{HbpA}$, from Leptospira interrogans serovar Lai. Infect. Immun. 2007, 75, 4582-4591. [CrossRef]

74. Louvel, H.; Saint Girons, I.; Picardeau, M. Isolation and characterization of FecA-and FeoB-mediated iron acquisition systems of the spirochete Leptospira biflexa by random insertional mutagenesis. J. Bacteriol. 2005, 187, 3249-3254. [CrossRef]

75. Chang, M.Y.; Cheng, Y.C.; Hsu, S.H.; Ma, T.L.; Chou, L.F.; Hsu, H.H.; Pan, R.L. Leptospiral outer membrane protein LipL32 induces inflammation and kidney injury in zebrafish larvae. Sci. Rep. 2016, 6, 27838. [CrossRef]

76. Carvalho, E.; Barbosa, A.S.; Gómez, R.M.; Cianciarullo, A.M.; Hauk, P.; Abreu, P.A.; Morais, Z.M. Leptospiral TlyC is an extracellular matrix-binding protein and does not present hemolysin activity. FEBS Lett. 2009, 2009 583, 1381-1385. [CrossRef]

77. Wunder Jr, E.A.; Slamti, L.; Suwondo, D.N.; Gibson, K.H.; Shang, Z.; Sindelar, C.V.; Picardeau, M. FcpB is a surface filament protein of the endoflagellum required for the motility of the spirochete Leptospira. Front. Cell. Infect. Microbiol. 2018, 8, 130. [CrossRef] [PubMed]

78. Thoduvayil, S.; Dhandapani, G.; Brahma, R.; Devasahayam Arokia Balaya, R.; Mangalaparthi, K.K.; Patel, K.; Pinto, S.M. Triton X-114 Fractionated Subcellular Proteome of Leptospira interrogans Shows Selective Enrichment of Pathogenic and Outer Membrane Proteins in the Detergent Fraction. Proteomics 2020, 20, 2000170. [CrossRef] [PubMed]

79. Yang, C.W.; Wu, M.S.; Pan, M.J. Leptospirosis renal disease. Nephrol. Dial. Transplant. 2001, 16, 73-77. [CrossRef] [PubMed] 
80. Zuerner, R.L.; Knudtson, W.; Bolin, C.A.; Trueba, G. Characterization of outer membrane and secreted proteins of Leptospira interrogans serovar pomona. Microb. Pathog. 1991, 10, 311-322. [CrossRef]

81. Tung, J.Y.; Yang, C.W.; Chou, S.W.; Lin, C.C.; Sun, Y.J. Calcium binds to LipL32, a lipoprotein from pathogenic Leptospira, and modulates fibronectin binding. J. Biol. Chem. 2010, 285, 3245-3252. [CrossRef]

82. Hoke, D.E.; Egan, S.; Cullen, P.A.; Adler, B. LipL32 is an extracellular matrix-interacting protein of Leptospira spp. and Pseudoalteromonas tunicata. Infect. Immun. 2008, 76, 2063-2069. [CrossRef]

83. Hauk, P.; Macedo, F.; Romero, E.C.; Vasconcellos, S.A.; De Morais, Z.M.; Barbosa, A.S.; Ho, P.L. In LipL32, the major leptospiral lipoprotein, the $\mathrm{C}$ terminus is the primary immunogenic domain and mediates interaction with collagen IV and plasma fibronectin. Infect. Immun. 2008, 76, 2642-2650. [CrossRef]

84. Witchell, T.D.; Eshghi, A.; Nally, J.E.; Hof, R.; Boulanger, M.J.; Wunder, E.A.; Ko, A.I.; Haake, D.A.; Cameron, C.E. Posttranslational Modification of LipL32 during Leptospira interrogans Infection. Plos Negl. Trop. Dis. 2014, 8, e3280:1-e3280:13. [CrossRef]

85. Wang, H.; Wu, Y.; Ojcius, D.M.; Yang, X.F.; Zhang, C.; Ding, S.; Lin, X.; Yan, J. Leptospiral hemolysins induce proinflammatory cytokines through toll-like receptor 2-and 4-mediated JNK and NF- KB signaling pathways. PLoS ONE 2012, 7, e42266:1-e42266:15. [CrossRef]

86. Yang, C.W.; Hung, C.C.; Wu, M.S.; Tian, Y.C.; Chang, C.T.; Pan, M.J.; Vandewalle, A. Toll-like receptor 2 mediates early inflammation by leptospiral outer membrane proteins in proximal tubule cells. Kidney Int. 2006, 69, 815-822. [CrossRef] [PubMed]

87. Lo, Y.Y.; Hsu, S.H.; Ko, Y.C.; Hung, C.C.; Chang, M.Y.; Hsu, H.H.; Pan, M.J.; Chen, Y.W.; Lee, C.H.; Tseng, F.G.; et al. Essential calcium-binding cluster of Leptospira LipL32 protein for inflammatory responses through the Toll-like receptor 2 pathway. J. Biol. Chem. 2013, 288, 12335-12344. [CrossRef] [PubMed]

88. Ahmed, S.A.; Sandai, D.A.; Musa, S.; Hock, H.C.; Riadzi, M.; Leong, L.K.; Hock, T.T. Rapid Diagnosis of Leptospirosis by Multiplex PCR. Malays. J. Med. Sci. 2012, 19, 9-16. [PubMed]

89. Tarigan, S. Recombinant LipL32 Protein for Leptospirosis Detection in Indonesia. Procedia Chem. 2016, 18, 18-25. [CrossRef]

90. Shang, E.S.; Exner, M.M.; Summers, T.A.; Martinich, C.; Champion, C.I.; Hancock, R.E.W.; Haake, D.A. The rare outer membrane protein, OmpL1, of pathogenic Leptospira species is a heat-modifiable porin. Infect. Immun. 1995, 63, 3174-3181. [CrossRef] [PubMed]

91. Dong, H.; Hu, Y.; Xue, F.; Sun, D.; Ojcius, D.M.; Mao, Y.; Yan, J. Characterization of the ompL1 gene of pathogenic Leptospira species in China and cross-immunogenicity of the OmpL1 protein. BMC Microbiol. 2008, 8, 223:1-223:12. [CrossRef]

92. Barnett, J.K.; Barnett, D.; Bolin, C.A.; Summers, T.A.; Wagar, E.A.; Cheville, N.F.; Hartskeerl, R.A.; Haake, D.A. Expression and distribution of leptospiral outer membrane components during renal infection of hamsters. Infect. Immun. 1999, 67, 853-861. [CrossRef]

93. Lin, X.; Sun, A.; Ruan, P.; Zhang, Z.; Yan, J. Characterization of conserved combined T and B cell epitopes in Leptospira interrogans major outer membrane proteins OmpL1 and LipL41. Bmc Microbiol. 2011, 11, 21:1-21:9. [CrossRef]

94. Haake, D.A.; Mazel, M.K.; McCoy, A.M.; Milward, F.; Chao, G.; Matsunaga, J.; Wagar, E.A. Leptospiral outer membrane proteins OmpL1 and LipL41 exhibit synergistic immunoprotection. Infect. Immun. 1999, 67, 6572-6582. [CrossRef]

95. Koizumi, N.; Watanabe, H. Molecular cloning and characterization of a novel leptospiral lipoprotein with OmpA domain. Fems Microbiol. Lett. 2003, 226, 215-219. [CrossRef]

96. Palaniappan, R.U.M.; Chang, Y.F.; Jusuf, S.S.D.; Artiushin, S.; Timoney, J.F.; McDonough, S.P.; Barr, S.C.; Divers, T.J.; Simpson, K.W.; McDonough, P.L.; et al. Cloning and molecular characterization of an immunogenic LigA protein of Leptospira interrogans. Infect. Immun. 2002, 70, 5924-5930. [CrossRef] [PubMed]

97. Palaniappan, R.U.M.; Chang, Y.F.; Hassan, F.; McDonough, S.P.; Pough, M.; Barr, S.C.; Simpson, K.W.; Mohammed, H.O.; Shin, S.; McDonough, P.; et al. Expression of leptospiral immunoglobulin-like protein by Leptospira interrogans and evaluation of its diagnostic potential in a kinetic ELISA. J. Med. Microbiol. 2004, 53, 975-984. [CrossRef] [PubMed]

98. Cerqueira, G.M.; McBride, A.J.A.; Picardeau, M.; Ribeiro, S.G.; Moreira, Â.N.; Morel, V.; Reis, M.G.; Ko, A.I.; Dellagostin, O.A. Distribution of the leptospiral immunoglobulin-like (lig) genes in pathogenic Leptospira species and application of ligB to typing leptospiral isolates. J. Med. Microbiol. 2009, 58, 1173-1181. [CrossRef]

99. Isberg, R.R.; Voorhis, D.L.; Falkow, S. Identification of invasin: A protein that allows enteric bacteria to penetrate cultured mammalian cells. Cell 1987, 50, 769-778. [CrossRef]

100. Jerse, A.E.; Yu, J.; Tall, B.D.; Kaper, J.B. A genetic locus of enteropathogenic Escherichia coli necessary for the production of attaching and effacing lesions on tissue culture cells. Proc. Natl. Acad. Sci. USA 1990, 87, 7839-7843. [CrossRef] [PubMed]

101. Matsunaga, J.; Lo, M.; Bulach, D.M.; Zuerner, R.L.; Adler, B.; Haake, D.A. Response of Leptospira interrogans to physiologic osmolarity: Relevance in signaling the environment-to-host transition. Infect. Immun. 2007, 75, 2864-2874. [CrossRef]

102. Matsunaga, J.; Sanchez, Y.; Xu, X.; Haake, D.A. Osmolarity, a key environmental signal controlling expression of leptospiral proteins LigA and LigB and the extracellular release of LigA. Infect. Immun. 2005, 73, 70-78. [CrossRef]

103. Lin, Y.P.; Chang, Y.F. A domain of the Leptospira LigB contributes to high affinity binding of fibronectin. Biochem. Biophys. Res. Commun. 2007, 362, 443-448. [CrossRef]

104. Croda, J.; Ramos, J.G.R.; Matsunaga, J.; Queiroz, A.; Homma, A.; Riley, L.W.; Haake, D.A.; Reis, M.G.; Ko, A.I. Leptospira immunoglobulin-like proteins as a serodiagnostic marker for acute leptospirosis. J. Clin. Microbiol. 2007, 45, 1528-1534. [CrossRef] 
105. Koizumi, N.; Watanabe, H. Leptospiral immunoglobulin-like proteins elicit protective immunity. Vaccine 2004, $22,1545-1552$. [CrossRef]

106. Barbosa, A.S.; Abreu, P.A.E.; Neves, F.O.; Atzingen, M.V.; Watanabe, M.M.; Vieira, M.L.; Morais, Z.M.; Vasconcellos, S.A.; Nascimento, A.L.T.O. A newly identified leptospiral adhesin mediates attachment to laminin. Infect. Immun. 2006, 74, 6356-6364. [CrossRef] [PubMed]

107. Verma, A.; Hellwage, J.; Artiushin, S.; Zipfel, P.F.; Kraiczy, P.; Timoney, J.F.; Stevenson, B. LfhA, a novel factor H-binding protein of Leptospira interrogans. Infect. Immun. 2006, 74, 2659-2666. [CrossRef] [PubMed]

108. Zipfel, P.F.; Skerka, C.; Hellwage, J.; Jokiranta, S.T.; Meri, S.; Brade, V.; Kraiczy, P.; Noris, M.; Remuzzi, G. Factor H family proteins: On complement, microbes and human diseases. In Proceedings of the Biochemical Society Transactions. Biochem. Soc. Trans. 2002, 30, 971-978. [CrossRef] [PubMed]

109. Vieira, M.L.; Vasconcellos, S.A.; Gonçales, A.P.; De Morais, Z.M.; Nascimento, A.L.T.O. Plasminogen acquisition and activation at the surface of Leptospira species lead to fibronectin degradation. Infect. Immun. 2009, 77, 4092-4101. [CrossRef]

110. Vieira, M.L.; Atzingen, M.V.; Oliveira, R.; Mendes, R.S.; Domingos, R.F.; Vasconcellos, S.A.; Nascimento, A.L.T.O. Plasminogen binding proteins and plasmin generation on the surface of Leptospira spp.: The contribution to the bacteria-host interactions. J. Biomed. Biotechnol. 2012, 2012, 758513:1-758513:17. [CrossRef]

111. Takabe, K.; Tahara, H.; Islam, M.S.; Affroze, S.; Kudo, S.; Nakamura, S. Viscosity-dependent variations in the cell shape and swimming manner of Leptospira. Microbiology 2017, 163, 153-160. [CrossRef]

112. Li, C.; Motaleb, M.A.; Sal, M.; Goldstein, S.F.; Charon, N.W. Spirochete periplasmic flagella and motility. J. Mol. Microbiol. Biotechnol. 2000, 2, 345-354.

113. Ritchie, A.E.; Ellinghausen, H.C. Electron Microscopy of Leptospires. I. Anatomical Features of Leptospira pomona. J. Bacteriol. 1965, 89, 223-233. [CrossRef]

114. Lambert, A.; Picardeau, M.; Haake, D.A.; Sermswan, R.W.; Srikram, A.; Adler, B.; Murray, G.A. Flaa proteins in Leptospira interrogans are essential for motility and virulence but are not required for formation of the flagellum sheath. Infect. Immun. 2012, 80, 2019-2025. [CrossRef]

115. Pillot, J.; Ryter, A. Structure des spirochètes. 1. Etude des generes Treponema, Borrelia et Leptospira au microscope electronique [Structure of spirochetes. 1. Study of the genera Treponema, Borrelia and Leptospira by the electron microscope]. Ann. Inst. Pasteur 1965, 108, 791-804.

116. Listgarten, M.A.; Socransky, S.S. Electron Microscopy of Axial Fibrils, Outer Envelope, and Cell Division of Certain Oral Spirochetes. J. Bacteriol. 1964, 88, 1087-1103. [CrossRef] [PubMed]

117. Raddi, G.; Morado, D.R.; Yan, J.; Haake, D.A.; Yang, X.F.; Liu, J. Three-dimensional structures of pathogenic and saprophytic leptospira species revealed by cryo-electron tomography. J. Bacteriol. 2012, 194, 1299-1306. [CrossRef] [PubMed]

118. Zhao, X.; Norris, S.J.; Liu, J. Molecular architecture of the bacterial flagellar motor in cells. Biochemistry 2014, 53, 4323-4333. [CrossRef] [PubMed]

119. Moon, K.H.; Zhao, X.; Manne, A.; Wang, J.; Yu, Z.; Liu, J.; Motaleb, M.A. Spirochetes flagellar collar protein FlbB has astounding effects in orientation of periplasmic flagella, bacterial shape, motility, and assembly of motors in Borrelia burgdorferi. Mol. Microbiol. 2016, 102, 336-348. [CrossRef] [PubMed]

120. Bourhy, P.; Collet, L.; Clément, S.; Huerre, M.; Ave, P.; Giry, C.; Pettinelli, F.; Picardeau, M. Isolation and characterization of new Leptospira genotypes from patients in Mayotte (Indian Ocean). Plos Negl. Trop. Dis. 2010, 4, e724:1-e724:10. [CrossRef]

121. Mogensen, T.H. Pathogen recognition and inflammatory signaling in innate immune defenses. Clin. Microbiol. Rev. 2009, 22, 240-273. [CrossRef]

122. Isogai, E.; Isogai, H.; Kurebayashi, Y.; Ito, N. Biological activities of Leptospiral Lipopolysaccharide. Zent. Für Bakteriol. Mikrobiol. Und Hyg. Abt. 1 Orig. A 1986, 261, 53-64. [CrossRef]

123. Bulach, D.M.; Kalambaheti, T.; de la Peña-Moctezuma, A.; Adler, B. Lipopolysaccharide biosynthesis in Leptospira. J. Mol. Microbiol. Biotechnol. 2000, 2, 375-380.

124. Nally, J.E.; Chow, E.; Fishbein, M.C.; Blanco, D.R.; Lovett, M.A. Changes in lipopolysaccharide O antigen distinguish acute versus chronic Leptospira interrogans infections. Infect. Immun. 2005, 73, 3251-3260. [CrossRef]

125. Adachi, Y.; Yanagawa, R. Inhibition of leptospiral agglutination by the type specific main antigens of leptospiras. Infect. Immun. 1977, 17, 466-467. [CrossRef]

126. Faine, S.; Vanderhoeden, J. Virulence-Linked Colonial and Morphological Variation in Leptospira. J. Bacteriol. 1964, 88, 1493-1496. [CrossRef] [PubMed]

127. Adler, B.; Faine, S.; Yanagawa, R. Comparative studies on two antigens (F4 and TM) extracted from leptospires. J. Clin. Microbiol. 1980, 12, 7-9. [CrossRef] [PubMed]

128. Vinaiphat, A.; Thongboonkerd, V. Heat Shock Proteins in Leptospirosis. In Heat Shock Proteins in Veterinary Medicine and Sciences; Asea, A.A., Kaur, P., Eds.; Springer International Publishing: Basel, Switzerland, 2017; pp. 361-374.

129. Natarajaseenivasan, K.; Shanmughapriya, S.; Velineni, S.; Artiushin, S.C.; Timoney, J.F. Cloning, Expression, and Homology Modeling of GroEL Protein from Leptospira interrogans Serovar Autumnalis Strain N2. Genom. Proteom. Bioinform. 2011, 9, 151-157. [CrossRef] 
130. Atzingen, M.V.; Rodriguez, D.; Siqueira, G.H.; Leite, L.C.C.; Nascimento, A.L.T.O. Induction of boosted immune response in mice by leptospiral surface proteins expressed in fusion with DnaK. Biomed. Res. Int. 2014, 2014, 564285:1-564285:11. [CrossRef] [PubMed]

131. Evangelista, K.V.; Coburn, J. Leptospira as an emerging pathogen: A review of its biology, pathogenesis and host immune responses. Future Microbiol. 2010, 5, 1413-1425. [CrossRef]

132. Martins-Pinheiro, M.P.; Schons-Fonseca, L.F.; Da Silva, J.B.; Domingos, R.H.; Santos Momo, L.H.; Quirino Simões, A.C.; Lee Ho, P.; Da Costa, R.M.A. Genomic survey and expression analysis of DNA repair genes in the genus Leptospira. Mol. Genet. Genom. 2016, 291, 703-722. [CrossRef]

133. Fouts, D.E.; Matthias, M.A.; Adhikarla, H.; Adler, B.; Amorim-Santos, L.; Berg, D.E.; Bulach, D.; Buschiazzo, A.; Chang, Y.F.; Galloway, R.L.; et al. What Makes a Bacterial Species Pathogenic?:Comparative Genomic Analysis of the Genus Leptospira. PLos Negl. Trop. Dis. 2016, 10, e0004403:1-e0004403:57. [CrossRef]

134. Haake, D.A.; Levett, P.N. Leptospirosis in humans. Curr. Top. Microbiol. Immunol. 2015, 387, 65-97. [CrossRef]

135. Charon, N.W.; Greenberg, E.P.; Koopman, M.B.H.; Limberger, R.J. Spirochete chemotaxis, motility, and the structure of the spirochetal periplasmic flagella. Res. Microbiol. 1992, 143, 597-603. [CrossRef]

136. Stern, E.J.; Galloway, R.; Shadomy, S.V.; Wannemuehler, K.; Atrubin, D.; Blackmore, C.; Wofford, T.; Wilikins, P.P.; Ari, M.D.; Harris, L.; et al. Outbreak of leptospirosis among adventure race participants in Florida, 2005. Clin. Infect. Dis. 2010, 50, 843-849. [CrossRef]

137. Mwachui, M.A.; Crump, L.; Hartskeerl, R.; Zinsstag, J.; Hattendorf, J. Environmental and Behavioural Determinants of Leptospirosis Transmission: A Systematic Review. PLos Negl. Trop. Dis. 2015, 9, e0003843:1-e0003843:15. [CrossRef] [PubMed]

138. Lee, H.S.; Khong, N.V.; Xuan, H.N.; Nghia, V.B.; Nguyen-Viet, H.; Grace, D. Sero-prevalence of specific Leptospira serovars in fattening pigs from 5 provinces in Vietnam. BMC Vet. Res. 2017, 13, 125:1-125:7. [CrossRef] [PubMed]

139. Jung, B.Y.; Lee, K.W.; Ha, T.Y. Seroprevalence of Leptospira spp. in Clinically Healthy Racing Horses in Korea. J. Vet. Med. Sci. 2010, 72, 197-201. [CrossRef] [PubMed]

140. Verma, A.; Stevenson, B.; Adler, B. Leptospirosis in horses. Vet. Microbiol. 2013, 167, 61-66. [CrossRef] [PubMed]

141. Pires, B.C.; Grapiglia, J.B.; Moreira, L.; Jaeger, L.H.; Carvalho-Costa, F.A.; Lilenbaum, W. Occurrence of uterine carriers for Leptospira interrogans on slaughtered cows. Microb. Pathog. 2018, 114, 163-165. [CrossRef]

142. Sant'Anna, R.; Vieira, A.S.; Grapiglia, J.; Lilenbaum, W. High number of asymptomatic dogs as leptospiral carriers in an endemic area indicates a serious public health concern. Epidemiol. Infect. 2017, 145, 1852-1854. [CrossRef]

143. Kurilung, A.; Keeratipusan, C.; Suriyaphol, P.; Prapasarakul, N. Draft genome sequence of a Leptospira interrogans strain isolated from the urine of an asymptomatic dog in Thailand. Genome Announc. 2018, 6, e01140-17:1-e01140-17:2. [CrossRef]

144. Levett, P.N.; Morey, R.E.; Galloway, R.L.; Steigerwalt, A.G. Leptospira broomii sp. nov., isolated from humans with leptospirosis. Int. J. Syst. Evol. Microbiol. 2006, 56, 671-673. [CrossRef]

145. De Oliveira, D.; Figueira, C.P.; Zhan, L.; Pertile, A.C.; Pedra, G.G.; Gusmão, I.M.; Wunder, E.A.; Rodrigues, G.; Ramos, E.A.G.; Ko, A.I.; et al. Leptospira in breast tissue and milk of urban Norway rats (Rattus norvegicus). Epidemiol. Infect. 2016, 37, 3147-3158. [CrossRef]

146. Harrison, N.A.; Fitzgerald, W.R. Leptospirosis-Can it be a sexually transmitted disease? Postgrad. Med. J. 1988, 64, 163-164. [CrossRef]

147. Lau, C.L.; Townell, N.; Stephenson, E.; van den Berg, D.; Craig, S.B. Leptospirosis: An important zoonosis acquired through work, play and travel. Aust. J. Gen. Pract. 2018, 47, 105-110. [CrossRef] [PubMed]

148. Bharti, A.R.; Nally, J.E.; Ricaldi, J.N.; Matthias, M.A.; Diaz, M.M.; Lovett, M.A.; Levett, P.N.; Gilman, R.H.; Willig, M.R.; Gotuzzo, E.; et al. Leptospirosis: A zoonotic disease of global importance. Lancet Infect. Dis. 2003, 3, 757-771. [CrossRef]

149. Banfi, E.; Cinco, M.; Bellini, M.; Soranzo, M.R. The role of antibodies and serum complement in the interaction between macrophages and leptospires. J. Gen. Microbiol. 1982, 128, 813-816. [CrossRef] [PubMed]

150. Que-Gewirth, N.L.S.; Ribeiro, A.A.; Kalb, S.R.; Cotter, R.J.; Bulach, D.M.; Adler, B.; Saint Girons, I.; Werts, C.; Raetz, C.R.H. A methylated phosphate group and four amide-linked acyl chains in Leptospira interrogans lipid A: The membrane anchor of an unusual lipopolysaccharide that activates TLR2. J. Biol. Chem. 2004, 279, 25420-25429. [CrossRef] [PubMed]

151. Goris, M.G.A.; Wagenaar, J.F.P.; Hartskeerl, R.A.; van Gorp, E.C.M.; Schuller, S.; Monahan, A.M.; Nally, J.E.; van der Poll, T.; van't Veer, C. Potent Innate Immune Response to Pathogenic Leptospira in Human Whole Blood. PLoS ONE 2011, 6, e18279:1e18279:10. [CrossRef] [PubMed]

152. Li, S.; Ojcius, D.M.; Liao, S.; Li, L.; Xue, F.; Dong, H.; Yan, J. Replication or death: Distinct fates of pathogenic Leptospira strain Lai within macrophages of human or mouse origin. Innate Immun. 2010, 16, 80-92. [CrossRef]

153. Toma, C.; Okura, N.; Takayama, C.; Suzuki, T. Characteristic features of intracellular pathogenic Leptospira in infected murine macrophages. Cell. Microbiol. 2011, 13, 1783-1792. [CrossRef] [PubMed]

154. Barocchi, M.A.; Ko, A.I.; Galvão Reis, M.; McDonald, K.L.; Riley, L.W. Rapid translocation of polarized MDCK cell monolayers by Leptospira interrogans, an invasive but nonintracellular pathogen. Infect. Immun. 2002, 70, 6926-6932. [CrossRef]

155. Murray, G.L. The molecular basis of leptospiral pathogenesis. Curr. Top. Microbiol. Immunol. 2015, 387, 139-185. [CrossRef]

156. Fernandes, L.G.; Siqueira, G.H.; Teixeira, A.R.F.; Silva, L.P.; Figueredo, J.M.; Cosate, M.R.; Vieira, M.L.; Nascimento, A.L.T.O. Leptospira spp.: Novel insights into host-pathogen interactions. Vet. Immunol. Immunopathol. 2016, 176, 50-57. [CrossRef] 
157. Liu, Y.; Zheng, W.; Li, L.; Mao, Y.; Yan, J. Pathogenesis of leptospirosis: Interaction of Leptospira interrogans with in vitro cultured mammalian cells. Med. Microbiol. Immunol. 2007, 196, 233-239. [CrossRef]

158. Zhang, L.; Zhang, C.; Ojcius, D.M.; Sun, D.; Zhao, J.; Lin, X.; Li, L.; Li, L.; Yan, J. The mammalian cell entry (Mce) protein of pathogenic Leptospira species is responsible for RGD motif-dependent infection of cells and animals. Mol. Microbiol. 2012, 83, 1006-1023. [CrossRef]

159. Adler, B. Pathogenesis of leptospirosis: Cellular and molecular aspects. Vet. Microbiol. 2014, 172, 353-358. [CrossRef]

160. Satiya, J.; Gupta, N.M.; Parikh, M.P. Weil's Disease: A Rare Cause of Jaundice. Cureus 2020, 12, e8428:1-e8428:4. [CrossRef]

161. Nascimento, A.L.T.O.; Ko, A.I.; Martins, E.A.L.; Monteiro-Vitorello, C.B.; Ho, P.L.; Haake, D.A.; Verjovski-Almeida, S.; Hartskeerl, R.A.; Marques, M.V.; Oliveira, M.C.; et al. Comparative Genomics of Two Leptospira interrogans Serovars Reveals Novel Insights into Physiology and Pathogenesis. J. Bacteriol. 2004, 186, 2164-2172. [CrossRef]

162. Cagliero, J.; Villanueva, S.Y.A.M.; Matsui, M. Leptospirosis Pathophysiology: Into the Storm of Cytokines. Front. Cell. Infect. Microbiol. 2018, 8, 204:1-204:8. [CrossRef]

163. Adhikarla, H.; Wunder, E.A.; Mechaly, A.E.; Mehta, S.; Wang, Z.; Santos, L.; Bisht, V.; Diggle, P.; Murray, G.; Adler, B.; et al. Lvr, a Signaling System That Controls Global Gene Regulation and Virulence in Pathogenic Leptospira. Front. Cell. Infect. Microbiol. 2018, 8, 45:1-45:13. [CrossRef]

164. Rodríguez, N.M.P.; Galloway, R.; Blau, D.M.; Traxler, R.; Bhatnagar, J.; Zaki, S.R.; Rivera, A.; Torres, J.V.; Noyd, D.; SantiagoAlbizu, X.E.; et al. Case report: Case series of fatal Leptospira spp./dengue virus co-infections - Puerto Rico, 2010-2012. Am. J. Trop. Med. Hyg. 2014, 91, 760-765. [CrossRef]

165. Sachu, A.; Madhavan, A.; Vasudevan, A.; Vasudevapanicker, J. Prevalence of dengue and leptospirosis co-infection in a tertiary care hospital in south india. Iran. J. Microbiol. 2018, 10, 227-232.

166. Sharma, K.; Latha, P.; Kalawat, U. Coinfection of leptospirosis and dengue fever at a tertiary care center in South India. Sch. Res. J. 2012, 2, 12-16. [CrossRef]

167. Rawal, G.; Yadav, S.; Kumar, R. Zika virus: An overview. J. Fam. Med. Prim. Care 2016, 5, 523-527. [CrossRef]

168. Neaterour, P.; Rivera, A.; Galloway, R.L.; Negrón, M.G.; Rivera-Garcia, B.; Sharp, T.M. Case report: Fatal Leptospira spp./Zika virus coinfection-Puerto Rico, 2016. Am. J. Trop. Med. Hyg. 2017, 97, 1085-1087. [CrossRef]

169. Biron, A.; Cazorla, C.; Amar, J.; Pfannstie, A.; Dupont-Rouzeyrol, M.; Goarant, C. Zika virus infection as an unexpected finding in a leptospirosis patient. JMM Case Rep. 2016, 3, e005033:1-e05033:4. [CrossRef]

170. Wongsrichanalai, C.; Murray, C.K.; Gray, M.; Miller, R.S.; McDaniel, P.; Liao, W.J.; Pickard, A.L.; Magill, A.J. Co-infection with malaria and leptospirosis. Am. J. Trop. Med. Hyg. 2003, 68, 583-585. [CrossRef]

171. Markotić, A.; Kuzman, I.; Babić, K.; Gagro, A.; Ksiazek, T.G.; Rabatić, S.; Dekaris, D.; Nichol, S. Double Trouble: Hemorrhagic Fever with Renal Syndrome and Leptospirosis. Scand. J. Infect. Dis. 2002, 34, 221-224. [CrossRef]

172. Sunil-Chandra, N.P.; Clement, J.; Maes, P.; De Silva, H.J.; Van Esbroeck, M.; Van Ranst, M. Concomitant leptospirosis-hantavirus co-infection in acute patients hospitalized in Sri Lanka: Implications for a potentially worldwide underestimated problem. Epidemiol. Infect. 2015, 143, 2081-2093. [CrossRef]

173. Gamage, C.D.; Yasuda, S.P.; Nishio, S.; Kularatne, S.A.; Weerakoon, K.; Rajapakse, J.; Nwafor-Okoli, C.; Lee, R.B.; Obayashi, Y.; Yoshimatsu, K.; et al. Serological evidence of Thailand virus-related hantavirus infection among suspected leptospirosis patients in Kandy, Sri Lanka. Jpn. J. Infect. Dis. 2011, 64, 72-75.

174. Sonthayanon, P.; Chierakul, W.; Wuthiekanun, V.; Limmathurotsakul, D.; Amornchai, P.; Smythe, L.D.; Day, N.P.; Peacock, S.J. Short report: Molecular confirmation of co-infection by pathogenic leptospira spp. and orientia tsutsugamushi in patients with acute febrile illness in Thailand. Am. J. Trop. Med. Hyg. 2013, 89, 797-799. [CrossRef]

175. Watt, G.; Jongsakul, K.; Suttinont, C. Possible scrub typhus coinfections in Thai agricultural workers hospitalized with leptospirosis. Am. J. Trop. Med. Hyg. 2003, 68, 89-91. [CrossRef]

176. Arean, V.M. The pathologic anatomy and pathogenesis of fatal human leptospirosis (Weil's disease). Am. J. Pathol. 1962, 40, 393-423.

177. Daher, E.F.; Lima, R.S.A.; Silva Júnior, G.B.; Silva, E.C.; Karbage, N.N.N.; Kataoka, R.S.; Carvalho Júnior, P.C.; Magalhães, M.M.; Mota, R.M.S.; Libório, A.B. Clinical presentation of leptospirosis: A retrospective study of 201 patients in a metropolitan city of Brazil. Braz. J. Infect. Dis. 2010, 14, 3-10. [CrossRef]

178. Koe, S.L.L.; Tan, K.T.; Tan, T.C. Leptospirosis in pregnancy with pathological fetal cardiotocography changes. Singap. Med. J. 2014, 55, e20-e24. [CrossRef]

179. Edwards, G.A. Human leptospirosis. Medicine 1960, 39, 117-156. [CrossRef]

180. Budihal, S.V.; Perwez, K. Leptospirosis diagnosis: Competancy of various laboratory tests. J. Clin. Diagnos. Res. $2014,8,199-202$. [CrossRef]

181. Khaki, P. Clinical Laboratory Diagnosis of Human Leptospirosis. Int. J. Enteric Pathog. 2016, 4, e31859:1-e31859:7. [CrossRef]

182. Levett, P.N.; Branch, S.L.; Whittington, C.U.; Edwards, C.N.; Paxton, H. Two methods for rapid serological diagnosis of acute leptospirosis. Clin. Diagn. Lab. Immunol. 2001, 8, 349-351. [CrossRef]

183. Brown, P.D.; Carrington, D.G.; Gravekamp, C.; Van De Kemp, H.; Edwards, C.N.; Jones, S.R.; Prussia, P.R.; Garriques, S.; Terpstra, W.J.; Levett, P.N. Direct detection of leptospiral material in human postmortem samples. Res. Microbiol. 2003, 154, 581-586. [CrossRef]

184. Wysocki, J.; Liu, Y.; Shores, N. Leptospirosis with Acute Liver Injury. Bayl. Univ. Med. Cent. Proc. 2014, 27, 257-258. [CrossRef] 
185. Thresiamma, K.C.; Biju, A.; Chaurasia, R.; Sritharan, M.; Jayaprakash, C.; Thomas, S.; Eapen, C.K. Proteinuria in early detection of human leptospirosis. Int. J. Res. Med. Sci. 2017, 5, 646-652. [CrossRef]

186. Zuerner, R.L. Host response to Leptospira infection. In Leptospira and Leptospirosis; Adler, B., Ed.; Springer: Berlin/Heidenberg, Germany, 2015; pp. 223-250.

187. Sharma, J.; Suryavanshi, M. Thrombocytopenia in leptospirosis and role of platelet transfusion. Asian J. Transfus. Sci. 2007, 1 , 52-55. [CrossRef]

188. Galton, M.M.; Powers, D.K.; Hall, A.D.; Cornell, R.G. A rapid macroscopic slide screening test for the serodiagnosis of leptospirosis. Am. J. Vet. Res. 1958, 19, 505-512.

189. Musso, D.; La Scola, B. Laboratory diagnosis of leptospirosis: A challenge. J. Microbiol. Immunol. Infect. 2013, 46, 245-252. [CrossRef]

190. Chirathaworn, C.; Inwattana, R.; Poovorawan, Y.; Suwancharoen, D. Interpretation of microscopic agglutination test for leptospirosis diagnosis and seroprevalence. Asian Pac. J. Trop. Biomed. 2014, 4, S162-S164. [CrossRef]

191. Lizer, J.; Grahlmann, M.; Hapke, H.; Velineni, S.; Lin, D.; Kohn, B. Evaluation of a rapid IgM detection test for diagnosis of acute leptospirosis in dogs. Vet. Rec. 2017, 180, 517:1-517:5. [CrossRef]

192. Baburaj, P.; Nandkumar, V.S.; Khanna, L. Polymerase chain reaction in the diagnosis of leptospiral infection. J. Assoc. Phys. India 2006, 54, 339-340.

193. Wynwood, S.J.; Burns, M.-A.A.; Graham, G.C.; Weier, S.L.; McKay, D.B.; Craig, S.B. Validation of a Microsphere Immunoassay for Serological Leptospirosis Diagnosis in Human Serum by Comparison to the Current Gold Standard. Plos Negl. Trop. Dis. 2015, 9 , e0003636:1-e0003636:13. [CrossRef]

194. Terpstra, W.J.; Ligthart, G.S.; Schoone, G.J. ELISA for the detection of specific IgM and IgG in human leptospirosis. J. Gen. Microbiol. 1985, 131, 377-385. [CrossRef]

195. Hartman, E.G.; van Houten, M.; van der Donk, J.A.; Frik, J.F. Serodiagnosis of canine leptospirosis by solid-phase enzyme-linked immunosorbent assay. Vet. Immunol. Immunopathol. 1984, 7, 33-42. [CrossRef]

196. Adler, B.; Murphy, A.M.; Locarnini, S.A.; Faine, S. Detection of specific anti-leptospiral immunoglobulins M and G in human serum by solid-phase enzyme-linked immunosorbent assay. J. Clin. Microbiol. 1980, 11, 452-457. [CrossRef]

197. Desakorn, V.; Wuthiekanun, V.; Thanachartwet, V.; Sahassananda, D.; Chierakul, W.; Apiwattanaporn, A.; Day, N.P.; Limmathurotsakul, D.; Peacock, S.J. Accuracy of a commercial IgM ELISA for the diagnosis of human leptospirosis in Thailand. Am. J. Trop. Med. Hyg. 2012, 86, 524-527. [CrossRef]

198. Shekatkar, S.; Harish, B.N.; Parija, S.C. IgM Dot-ELISA Assay using prevalent Leptospira strain for diagnosis of leptospirosis. Parija Sc Int. J. Collab. Res. Intern. Med. Public Health 2010, 2, 3-8.

199. Rosa, M.I.; dos Reis, M.F.; Simon, C.; Dondossola, E.; Alexandre, M.C.; Colonetti, T.; Meller, F.O. ELISA IgM para diagnóstico de leptospirose: Revisão sistemática e meta-análise. Cienc. E Saude Coletiva 2017, 22, 4001-4012. [CrossRef] [PubMed]

200. Brandão, A.P.; Camargo, E.D.; Da Silva, E.D.; Silva, M.V.; Abrão, R.V. Macroscopic agglutination test for rapid diagnosis of human leptospirosis. J. Clin. Microbiol. 1998, 36, 3138-3142. [CrossRef] [PubMed]

201. Levett, P.N.; Whittington, C.U. Evaluation of the indirect hemagglutination assay for diagnosis of acute leptospirosis. J. Clin. Microbiol. 1998, 36, 11-14. [CrossRef]

202. Bajani, M.D.; Ashford, D.A.; Bragg, S.L.; Woods, C.W.; Aye, T.; Spiegel, R.A.; Plikaytis, B.D.; Perkins, B.A.; Phelan, M.; Levett, P.N.; et al. Evaluation of four commercially available rapid serologic tests for diagnosis of leptospirosis. J. Clin. Microbiol. 2003, 41, 803-809. [CrossRef] [PubMed]

203. Hatta, M.; Smits, H.L.; Gussenhoven, G.C.; Gooskens, J. Introduction of a rapid dipstick assay for the detection of leptospiraspecific immunoglobulin $\mathrm{M}$ antibodies in the laboratory diagnosis of leptospirosis in a hospital in Makassar, Indonesia. Southeast. Asian J. Trop. Med. Public Health 2000, 31, 515-520.

204. Gussenhoven, G.C.; Van Der Hoorn, M.A.W.G.; Goris, M.G.A.; Terpstra, W.J.; Hartskeerl, R.A.; Mol, B.W.; Van Ingen, C.W.; Smits, H.L. LEPTO dipstick, a dipstick assay for detection of Leptospira-specific immunoglobulin M antibodies in human sera. J. Clin. Microbiol. 1997, 35, 92-97. [CrossRef]

205. Tzur, A.; Moore, J.K.; Jorgensen, P.; Shapiro, H.M.; Kirschner, M.W. Optimizing Optical Flow Cytometry for Cell Volume-Based Sorting and Analysis. PLoS ONE 2011, 6, e16053:1-e16053:9. [CrossRef]

206. Adan, A.; Alizada, G.; Kiraz, Y.; Baran, Y.; Nalbant, A. Flow cytometry: Basic principles and applications. Crit. Rev. Biotechnol. 2017, 37, 163-176. [CrossRef]

207. Headland, S.E.; Jones, H.R.; D’Sa, A.S.V.; Perretti, M.; Norling, L.V. Cutting-edge analysis of extracellular microparticles using imagestreamx imaging flow cytometry. Sci. Rep. 2014, 4, 1-10. [CrossRef]

208. McKinnon, K.M. Flow cytometry: An overview. Curr. Protoc. Immunol. 2018, 2018, 5.1.1-5.1.11. [CrossRef] [PubMed]

209. Yitzhaki, S.; Barnea, A.; Keysary, A.; Zahavy, E. New approach for serological testing for leptospirosis by using detection of leptospira agglutination by flow cytometry light scatter analysis. J. Clin. Microbiol. 2004, 42, 1680-1685. [CrossRef] [PubMed]

210. Lovitt, R.W.; Wright, C.J. Microscopy: Light Microscopy. In Encyclopedia of Food Microbiology, 2nd ed.; Batt, C.A., Tortorello, M.L., Eds.; Academic Press: Cambridge, MA, USA, 2014; pp. 684-692.

211. Chandrasekaran, S.; Gomathi, S. A standard screening test for the early and rapid diagnosis of leptospirosis. Indian J. Med. Microbiol. 2004, 22, 23-27. [PubMed] 
212. Gunasekara, C.P.; Sumaiha, M.H.F.; Damayanthi, M.K.S.; Weerasekera, M.M.; Fernando, S.S.N. Utility of a modified silver staining technique for detection of Leptospira. Sri Lankan J. Infect. Dis. 2017, 7, 85-91. [CrossRef]

213. Azizi, S.; Kheirandish, R.; Rahimi, E. Comparison of polymerase chain reaction and Warthin-Starry techniques to detect Leptospira spp. in kidneys of slaughtered cattle. Onderstepoort J. Vet. Res. 2014, 81, e1-e6. [CrossRef] [PubMed]

214. Wild, C.J.; Greenlee, J.J.; Bolin, C.A.; Barnett, J.K.; Haake, D.A.; Cheville, N.F. An improved immunohistochemical diagnostic technique for canine leptospirosis using antileptospiral antibodies on renal tissue. J. Vet. Diagn. Investig. 2002, 14, 20-24. [CrossRef]

215. Mythri, B.A. Laboratory Diagnosis of Leptospirosis: A Review. J. Evol. Med. Dent. Sci. 2015, 4, 8759-8769. [CrossRef]

216. Ellinghausen, H.C.; Mccullough, W.G. Nutrition of Leptospira Pomona And Growth of 13 Other Serotypes: A Serum-Free Medium Employing Oleic Albumin Complex. Am. J. Vet. Res. 1965, 26, 39-44.

217. Miraglia, F.; De Moraes, Z.M.; Melville, P.A.; Dias, R.A.; Vasconcellos, S.A. Emjh medium with 5-fluorouracil and nalidixic acid associated with serial dilution technique used to recover leptospira spp from experimentally contaminated bovine semen. Braz. J. Microbiol. 2009, 40, 189-193. [CrossRef]

218. Bal, A.E.; Gravekamp, C.; Hartskeerl, R.A.; De Meza-Brewster, J.; Korver, H.; Terpstra, W.J. Detection of leptospires in urine by PCR for early diagnosis of leptospirosis. J. Clin. Microbiol. 1994, 32, 1894-1898. [CrossRef]

219. Shafighi, T.; Zahraei Salehi, T.; Abdollahpour, G.; Asadpour, L.; Akbarein, H.; Salehzadeh, A. Molecular detection of Leptospira spp. in the urine of cattle in northern Iran. Iran. J. Vet. Res. 2014, 15, 402-405. [CrossRef] [PubMed]

220. Savio, M.L.; Rossi, C.; Fusi, P.; Tagliabue, S.; Pacciarini, M.L. Detection and identification of Leptospira interrogans serovars by PCR coupled with restriction endonuclease analysis of amplified DNA. J. Clin. Microbiol. 1994, 32, 935-941. [CrossRef] [PubMed]

221. Brown, P.D.; Gravekamp, C.; Carrington, D.G.; Van De Kemp, H.; Hartskeerl, R.A.; Edwards, C.N.; Everard, C.O.R.; Terpstra, W.J.; Levett, P.N. Evaluation of the polymerase chain reaction for early diagnosis of leptospirosis. J. Med. Microbiol. 1995, 43, 110-114. [CrossRef] [PubMed]

222. Villumsen, S.; Pedersen, R.; Krogfelt, K.A.; Jensen, J.S. Expanding the Diagnostic Use of PCR in Leptospirosis: Improved Method for DNA Extraction from Blood Cultures. PLoS ONE 2010, 5, e12095:1-e12095:7. [CrossRef]

223. Merien, F.; Portnoi, D.; Bourhy, P.; Charavay, F.; Berlioz-Arthaud, A.; Baranton, G. A rapid and quantitative method for the detection of Leptospira species in human leptospirosis. FEMS Microbiol. Lett. 2005, 249, 139-147. [CrossRef]

224. Natarajaseenivasan, K.; Raja, V.; Narayanan, R. Rapid diagnosis of leptospirosis in patients with different clinical manifestations by $16 \mathrm{~S}$ rRNA gene based nested PCR. Saudi J. Biol. Sci. 2012, 19, 151-155. [CrossRef]

225. Nassi, F.; Seixas, F.K.; Dorneles Jouglard, S.D.; Simionatto, S.; Silva, E.F.; Seyffert, N.; Brod, C.S.; Dellagostin, O.A. Leptospirosis diagnosis using nested-PCR. Braz. J. Microbiol. 2003, 34, 90-92. [CrossRef]

226. Blanco, R.M.; Romero, E.C. Evaluation of nested polymerase chain reaction for the early detection of Leptospira spp. DNA in serum samples from patients with leptospirosis. Diagn. Microbiol. Infect. Dis. 2014, 78, 343-346. [CrossRef]

227. Lim, V.K. Leptospirosis: A re-emerging infection. Malays. J. Pathol. 2011, 33, 1-5.

228. Gasem, M.H.; Hadi, U.; Alisjahbana, B.; Tjitra, E.; Hapsari, M.M.D.E.A.H.; Lestari, E.S.; Aman, A.T.; Lokida, D.; Salim, G.; Kosasih, H.; et al. Leptospirosis in Indonesia: Diagnostic challenges associated with atypical clinical manifestations and limited laboratory capacity. BMC Infect. Dis. 2020, 20, 179:1-179:11. [CrossRef]

229. Koizumi, N.; Nakajima, C.; Harunari, T.; Tanikawa, T.; Tokiwa, T.; Uchimura, E.; Furuya, T.; Mingala, C.N.; Villanueva, M.A.; Ohnishi, M.; et al. A new loop-mediated isothermal amplification method for rapid, simple, and sensitive detection of Leptospira spp. in urine. J. Clin. Microbiol. 2012, 50, 2072-2074. [CrossRef] [PubMed]

230. Blasdell, K.R.; Morand, S.; Perera, D.; Firth, C. Association of rodent-borne Leptospira spp. with urban environments in Malaysian Borneo. Plos Negl. Trop. Dis. 2019, 13, e0007141:1-e0007141:17. [CrossRef] [PubMed]

231. Roqueplo, C.; Kodjo, A.; Demoncheaux, J.P.; Scandola, P.; Bassene, H.; Diatta, G.; Sokhna, C.; Raoult, D.; Davoust, B.; Mediannikov, O. Leptospirosis, one neglected disease in rural Senegal. Vet. Med. Sci. 2019, 5, 536-544. [CrossRef] [PubMed]

232. Nozmi, N.; Samsudin, S.; Sukeri, S.; Shafei, M.N.; Wan Mohd, W.; Idris, Z.; Arifin, W.N.; Idris, N.; Saudi, S.; Abdullah, N.M.; et al. Low Levels of Knowledge, Attitudes and Preventive Practices on Leptospirosis among a Rural Community in Hulu Langat District, Selangor, Malaysia. Int. J. Environ. Res. Public Health 2018, 15, 693. [CrossRef]

233. Bierque, E.; Thibeaux, R.; Girault, D.; Soupé-Gilbert, M.E.; Goarant, C. A systematic review of Leptospira in water and soil environments. PLoS ONE 2020, 15, e227055:1-e227055:22. [CrossRef] 